\title{
Waste Isolation Pilot Plant Initial Report for PCB Disposal Authorization (40 CFR § 761.75[c])
}

March 19, 2002 


\section{TABLE OF CONTENTS}

1.0 INTRODUCTION $\ldots \ldots \ldots \ldots \ldots \ldots \ldots \ldots \ldots \ldots \ldots \ldots \ldots \ldots \ldots \ldots \ldots$

2.0 LOCATION OF THE DISPOSAL FACILITY $\ldots \ldots \ldots \ldots \ldots \ldots \ldots$

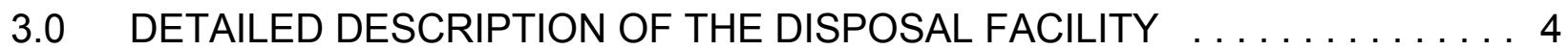

4.0 ENGINEERING REPORT ON TECHNICAL STANDARDS FOR CHEMICAL WASTE LANDFILLS $\ldots \ldots \ldots \ldots \ldots \ldots \ldots \ldots \ldots \ldots \ldots \ldots \ldots \ldots$

5.0 SAMPLING AND MONITORING EQUIPMENT AND FACILITIES AVAILABLE $\ldots \ldots \ldots \ldots \ldots \ldots \ldots \ldots \ldots \ldots \ldots \ldots \ldots \ldots \ldots \ldots \ldots \ldots$

6.0 EXPECTED WASTE VOLUMES OF PCB/TRU WASTE $\ldots \ldots \ldots \ldots \ldots \ldots 7$

7.0 GENERAL DESCRIPTION OF WASTE MATERIALS OTHER THAN PCBS . . . 8

8.0 DISPOSAL FACILITY OPERATIONS PLAN $\ldots \ldots \ldots \ldots \ldots \ldots \ldots$

9.0 FACILITY CONTINGENCY PLAN $\ldots \ldots \ldots \ldots \ldots \ldots \ldots \ldots \ldots$

10.0 FACILITY TRAINING PLAN $\ldots \ldots \ldots \ldots \ldots \ldots \ldots \ldots \ldots \ldots \ldots \ldots \ldots$

11.0 LOCAL, STATE, OR FEDERAL PERMITS OR APPROVALS $\ldots \ldots \ldots \ldots \ldots 9$

12.0 SCHEDULES OR PLANS FOR COMPLYING WITH THE APPROVAL

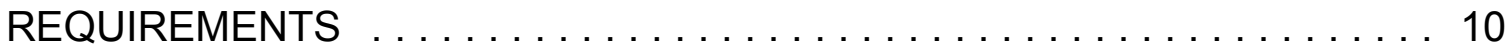

Attachment A General Site Plans and Design Drawings $\ldots \ldots \ldots \ldots \ldots \ldots 11$

Attachment B Engineering Report Describing the Manner in Which WIPP

Complies with the Requirements for Chemical Waste Landfills ... . 19

Attachment C Local, State, and Federal Permits or Approvals as of

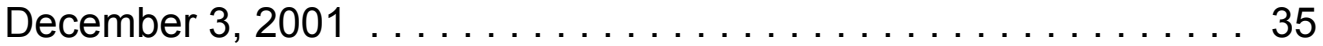

Attachment $D \quad$ List of Acronyms and Abbreviations ............... 42 


\subsection{INTRODUCTION}

This initial report is being submitted pursuant to Title 40 Code of Federal Regulations (CFR) $\S 761.75$ (c) to request authorization to allow the disposal of transuranic (TRU) wastes containing polychlorinated biphenyls (PCBs) which are duly regulated under the Toxic Substances Control Act (TSCA). Approval of this initial report will not affect the disposal of TRU or TRU mixed wastes that do not contain PCBs. This initial report also demonstrates how the Waste Isolation Pilot Plant (WIPP) meets or exceeds the technical standards for a Chemical Waste Landfill. Approval of this request will allow the U.S. Department of Energy (DOE) to dispose of approximately 88,000 cubic feet ( $\mathrm{ft}^{3}$ ) $\left(2,500\right.$ cubic meters $\left.\left[\mathrm{m}^{3}\right]\right)$ of TRU wastes containing PCBs subject to regulation under the TSCA. This approval will include only those PCB/TRU wastes, which the TSCA regulations allow for disposal of the $\mathrm{PCB}$ component in municipal solid waste facilities or chemical waste landfills (e.g., PCB remediation waste, PCB articles, and bulk PCB product waste).

Disposal of TRU waste by the DOE is congressionally mandated in Public Law 102-579 (as amended by the National Defense Authorization Act for Fiscal Year 1997, Pub. L. 104-201, referred to as the WIPP Land Withdrawal Act [LWA]). Portions of the TRU waste inventory contain hazardous waste constituents regulated under 40 CFR Parts 260 through 279, and/or PCBs and PCB Items regulated under 40 CFR Part 761. Therefore, the DOE TRU waste program must address the disposal requirements for these hazardous waste constituents and PCBs.

To facilitate the disposal of TRU wastes containing hazardous waste constituents, the owner/operators received a Hazardous Waste Facility Permit (HWFP) from the New Mexico Environment Department (NMED) on October 27, 1999. The permit allows the disposal of TRU wastes subject to hazardous waste disposal requirements (TRU mixed waste). Informational copies of this permit and other referenced documents are available from the WIPP website at http://www.wipp.ws/library/caolib.htm\#RCRA.

To facilitate the disposal of TRU wastes containing PCBs, the owner/operators are hereby submitting this initial report containing information required pursuant to the Chemical Waste Landfill Approval requirements in 40 CFR § 761.75(c). Although WIPP is defined as a miscellaneous unit and not a landfill by the New Mexico Hazardous Waste Act, WIPP meets or exceeds all applicable technical standards for chemical waste landfills by virtue of its design and programs as indicated in the Engineering Report (Attachment B). The layout of this initial report is consistent with requirements (i.e., Sections 2.0 through 12.0 following the sequence of 40 CFR $\S 761.75[\mathrm{c}][\mathrm{i}]$-[ix] with sections added to discuss the Contingency and Training Plans; and Attachment $B$ of this initial report addresses the requirements of 40 CFR $\S 761.75[b][1]$ through [9] in this order).

This initial report includes a description of three proposed changes that will be subject to "conditional approval." The first will allow the disposal of remote-handled (RH) PCB/TRU waste at WIPP. The second will allow the establishment of a central confirmation facility at WIPP. The third will allow for an increase in contact-handled 
$(\mathrm{CH})$ waste storage capacities. These proposed changes are discussed further in Section 3.3 of this initial report. "Conditional approval" of these requests would allow these activities at WIPP contingent upon:

- $\quad$ Approval of the HWFP modification (NMED) and Compliance Certification Application (CCA) change request (Environmental Protection Agency [EPA])

- Inspection of facility prior to implementing the change (if deemed necessary by the EPA)

- Written approval from the EPA

This initial report also includes the following three requests for waivers to the technical requirements for Chemical Waste Landfills pursuant to 40 CFR $\S 761.75(c)(4)$ :

- $\quad$ Hydrologic Conditions (40 CFR § 761.75[b][3])

- $\quad$ Monitoring Systems (40 CFR § 761.75[b][6])

- $\quad$ Leachate Collection (40 CFR § 761.75[b][7])

The details explaining the purpose and scope of these waivers are addressed by Attachment B to this initial report.

\section{$1.1 \quad$ Definitions}

Unless otherwise expressly provided herein, the terms used in this initial report shall have the meaning set forth in TSCA and/or their implementing regulations.

- $\quad$ "Contact-handled transuranic waste" (CH TRU waste) means transuranic waste with a surface dose rate not greater than 200 millirem per hour. [LWA]

- $\quad$ "Facility" means the Waste Isolation Pilot Plant (WIPP) owned by the DOE and located approximately twenty-six (26) miles southeast of Carlsbad, New Mexico (Attachment A, Figure 1), EPA I.D. Number NM4890139088. The WIPP facility comprises the entire complex within the WIPP Site Boundary as specified in the WIPP LWA, including all contiguous land, and structures, other appurtenances, and improvements to be used for management, storage, or disposal of PCB/TRU waste.

- $\quad$ "Owner/Operators" means the United States Department of Energy (DOE), an agency of the federal government, and the owner and co-operator of the WIPP facility; and Westinghouse TRU Solutions LLC, management and operating contractor (MOC) and co-operator of the WIPP facility.

- $\quad$ "PCB/TRU waste" refers to any TRU (radioactive) waste commingled with PCBs ( $>50 \mathrm{ppm}$ ) that may or may not contain hazardous constituents subject to regulation under the New Mexico Hazardous Waste Act. 
- $\quad$ "Remote-handled transuranic waste" (RH TRU waste) means transuranic waste with a surface dose rate 200 millirem per hour or greater. [LWA]

- $\quad$ "TRU waste" means waste containing more than 100 nanocuries of alphaemitting transuranic isotopes per gram of waste, with half-lives greater than 20 years, except for $(A)$ high-level radioactive waste; $(B)$ waste that the DOE Secretary has determined, with the concurrence of the EPA Administrator, does not need the degree of isolation required by the disposal regulations; or (C) waste that the Nuclear Regulatory Commission (NRC) has approved for disposal on a case-by-case basis in accordance with10 CFR Part 61.

[Pub. L. 102-579 (1992)]

- $\quad$ "TRU mixed waste" means TRU waste that is also a hazardous waste as defined by the Hazardous Waste Act and 20 New Mexico Administrative Code (NMAC) 4.1.200 (incorporating 40 CFR § 261.3).

\subsection{LOCATION OF THE DISPOSAL FACILITY (40 CFR § 761.75[C][1][i])}

Name of Facility: $\quad$ Waste Isolation Pilot Plant

Owner and Co-Operator: U.S. Department of Energy

P.O. Box 3090

Carlsbad, NM 88221

Co-Operator: $\quad$ Westinghouse TRU Solutions, LLC

P.O. Box 2078

Carlsbad, NM 88221

Responsible Officials: Inés Triay, Manager

DOE Carlsbad Field Office

John Lee, General Manager

Westinghouse TRU Solutions LLC

Facility Mailing Address: U.S. Department of Energy

P.O. Box 3090

Carlsbad, NM 88221

Facility Location:

26 miles southeast of Carlsbad in Eddy County, NM (Attachment A, Figure 1)

Telephone Number:

(505) 234-7300

U.S. EPA I.D. Number: NM4890139088

Geographic Location: $\quad 32^{\circ} 22^{\prime} 30^{\prime \prime} \mathrm{N} ; 103^{\circ} 47^{\prime} 30^{\prime \prime} \mathrm{W}$

Date Operations Began: March 26, 1999 


\subsection{DETAILED DESCRIPTION OF THE DISPOSAL FACILITY (40 CFR § 761.75[C][1][ii])}

WIPP is a facility designed to safely manage, store, and dispose of TRU and TRU mixed waste. Currently, only CH TRU and TRU mixed wastes are permitted by the NMED for storage or disposal at the WIPP facility; however, the owner/operators are requesting "conditional approval" of the proposed changes described below. PCB/TRU wastes will be stored in areas permitted under the HWFP.

The following description of the disposal facility is from the WIPP HWFP, Attachment A. Attachments $\mathrm{F}$ and M1 of the WIPP HWFP provide a more detailed description of the buildings/sections of the facility.

\subsection{Property Description}

The WIPP facility has been divided into functional areas as indicated in Attachment A, Figure 2. The Property Protection Area (PPA) is surrounded by a chain-link security fence, encompasses 34.16 acres, and provides security and protection for all major surface structures. The WIPP Off-Limits Area (not depicted) encloses the PPA, and contains approximately 1,454 acres. These areas define the WIPP exclusion zone within which certain activities, items, and material are prohibited. The final zone is marked by the WIPP Site Boundary (WIPP land withdrawal area) a 16-section federal land area under the jurisdiction of the DOE.

\subsection{Facility Type}

Three basic groups of structures are associated with the WIPP facility: surface structures, shafts, and underground structures. The layout and relative positions of these structures are illustrated in Attachment A, Figure 3.

The surface structures will accommodate the personnel, equipment, and support services required for the receipt, preparation, and transfer of PCB/TRU waste from the surface to the underground. There are two surface locations where PCB/TRU waste will be managed. The first area designated for managing PCB/TRU waste is the Parking Area Container Storage Unit (Parking Area Unit), an outside waste container storage area that extends south from the Waste Handling Building (WHB) to the railroad tracks (Attachment A, Figure 4). The Parking Area Unit provides storage space for loaded shipping containers with up to $1,591 \mathrm{ft}^{3}\left(45 \mathrm{~m}^{3}\right)$ of waste on an asphalt and concrete surface encompassing approximately 115,000 square feet $\left(\mathrm{ft}^{2}\right)$. The second area includes a portion of the WHB, of which $33,175 \mathrm{ft}^{2}$ are designated as the WHB Container Storage Unit (WHB Unit) for PCB/TRU waste management (Attachment A, Figure 5).

Four vertical shafts connect the surface facility to the underground (Attachment A, Figure 3). These are the waste shaft, the salt handling shaft, the exhaust shaft, and the air intake shaft. The waste shaft is the only shaft used to transport waste to the underground. The WIPP underground structures are located in a mined salt bed 
2,150 $\mathrm{ft}$ below the surface. The underground structures (Attachment A, Figure 6) include the underground Hazardous Waste Disposal Units (HWDU), an area for future underground HWDUs, the shaft pillar area, interconnecting drifts, and other areas unrelated to the HWFP and this initial report.

The underground HWDUs are defined as waste panels 1 through 8, each consisting of seven rooms and two access drifts. These access drifts are designated as panels 9 and 10 and will be used for waste emplacement once they are no longer necessary as access drifts. Each of the seven rooms in a panel is approximately $300 \mathrm{ft} \mathrm{long,} 33 \mathrm{ft}$ wide, and $13 \mathrm{ft}$ high; the rooms are separated by 100 -ft-thick salt columns. Panel 1 is expected to be filled by January 2003 , after which each subsequent panel will take approximately 2.5 years to fill after emplacement is initiated. These estimates are based on current and projected wastes shipping and emplacement rates. Currently, only panels 1 and 2 have been mined. Additional panels will be mined as needed in the future.

General site plans are included as Attachment A of this initial report.

\subsection{Proposed Changes}

Under TSCA Chemical Waste Landfill Approval (40 CFR $\S 761.75$ ), there is no formal process to request changes or modification to an approval. As a result, the EPA suggested that the owner/operators could request inclusion of a "conditional approval process" for proposed changes that will impact the information contained in this initial report. The owner/operators are therefore requesting "conditional approval" that the following planned facility modifications be considered as candidates for the conditional approval process:

- $\quad$ Allow the storage and disposal of RH PCB/TRU wastes at WIPP.

- $\quad$ Allow the establishment of a central confirmation facility at WIPP.

- $\quad$ Flexibility to the storage capacities for $\mathrm{CH}$ PCB/TRU wastes.

"Conditional approval" of these requests would allow these changes at WIPP contingent upon:

- $\quad$ Approval of the HWFP modification (NMED) and Compliance Certification Application (CCA) change request (Environmental Protection Agency [EPA]).

- Inspection of facility prior to implementing the change (if deemed necessary by the EPA).

- Written approval from the EPA Region VI. 


\subsection{1 $\mathrm{RH}$ PCB/TRU Wastes}

Approval of the RH PCB/TRU waste request will provide for safe disposal of these wastes. In addition, this change will provide for additional storage capacity in the Parking Area Unit and additional space in the WHB designated for the management of $\mathrm{RH}$ TRU wastes. This additional space in the WHB will provide for storage in the RH Bay, the Cask Unloading Room, the Hot Cell, the Transfer Cell, and the Facility Cask Loading Room. The operations plan for the management of these RH PCB/TRU wastes is described in Attachment B of this initial report.

\subsubsection{Central Confirmation Facility}

Approval of the central confirmation facility request will allow confirmation of DOE generator/storage site waste characterization at WIPP. In addition, this change will provide for an increased storage capacity necessary to facilitate the confirmation process. The increase will include additional space in the WHB designated for the management of $\mathrm{CH}$ TRU wastes awaiting confirmation. This additional space in the WHB will provide for storage in the Northwest Storage Area (Room 108), the Waste Container Storage Area, and Room 112. The operations plan describing the central confirmation process is included in Attachment B of this initial report.

\subsubsection{Additional Changes}

In the future, the owner/operators plan to seek additional storage capacity increases for $\mathrm{CH}$ PCB/TRU wastes. These changes will be based on safety and operational efficiency concerns. Under this conditional approval, increased storage capacities may be requested for existing storage areas (e.g., northeast storage area, shielded storage area, and TRUPACT-II dock [TRUDOCK] storage area) and/or new storage areas. The extent of the increase in storage has not been determined; however, it will be limited by other requirements such as safety, aisle space, emergency response, and equipment movement. These changes will not impact the operations plan except to increase storage capacities.

\subsection{ENGINEERING REPORT ON TECHNICAL STANDARDS FOR CHEMICAL WASTE LANDFILLS (40 CFR § 761.75[c][1][iii])}

A report outlining WIPP's compliance with Chemical Waste Landfill requirements is outlined in the Engineering Report (Attachment B of this initial report).

\subsection{SAMPLING AND MONITORING EQUIPMENT AND FACILITIES AVAILABLE (40 CFR § 761.75[c][1][iv])}

Although this information is required in accordance with 40 CFR $\S 761.75$ (c)(1)(iv), the owner/operators are requesting a waiver to the requirements to the Monitoring Systems 40 CFR $\S 761.75(\mathrm{~b})(6)$ as addressed in Attachment B of this initial report. 
To meet the requirements of Modules IV and $V$ of the HWFP, equipment, training, and personnel are available for sampling and monitoring volatile organic compound emissions, groundwater quality, and groundwater levels at the WIPP site. Under the HWFP, the owner/operators have also performed a background groundwater quality baseline as required by Module $V$ of the HWFP. The report outlining the results of this 2.5-year study (including PCBs) was completed and submitted in April 1998. The baseline study was performed using the seven water quality sampling program wells currently used for groundwater quality monitoring, and indicated that no PCBs were detected. ${ }^{1}$ In addition to groundwater quality monitoring, groundwater level measurements are taken periodically at numerous area wells to evaluate hydrologic conditions around the WIPP site.

Monitoring and sampling equipment includes two air quality monitoring stations in the underground, one upstream from the disposal area, and one downstream. In addition, there are seven groundwater monitoring wells; four wells are down-gradient and three are up-gradient of the repository. The owner/operators also have necessary equipment to collect, package, and transfer samples for analysis. Currently, the owner/operators conduct radiochemical analyses of smears, air filters, and bioassay samples on site; all other samples are sent to off-site laboratories.

\subsection{EXPECTED WASTE VOLUMES OF PCB/TRU WASTE (40 CFR § 761.75[c][1][V])}

Under the Land Withdrawal Act, WIPP will receive no more than $6.2 \mathrm{ft}^{3}\left(175,600 \mathrm{~m}^{3}\right)$ of waste. Ten panels will be constructed and used to dispose of waste. Only panels 1 through 3 are covered under the current HWFP. Each underground HWDU has seven rooms separated by pillars $100 \mathrm{ft}$ wide (Attachment A, Figure 6). The HWFP limits the volume of waste to be emplaced in each panel to $636,000 \mathrm{ft}^{3}\left(18,000 \mathrm{~m}^{3}\right)$, or 81,000 drum equivalents.

Approval of this request will allow the DOE to dispose of TRU wastes containing PCBs subject to regulation under the TSCA. This approval will include only those PCB/TRU wastes, which the TSCA regulations allow for disposal of the PCB component in municipal solid waste facilities or chemical waste landfills (e.g., PCB remediation waste, PCB articles, and bulk PCB product waste). Of the TRU and TRU mixed waste currently awaiting disposal at WIPP, only a small portion is known to contain PCBs. Additional quantities of PCB/TRU waste are expected to be generated during decontamination and decommissioning activities at DOE facilities. Current projections estimate the total quantity (existing and future) of PCB/TRU wastes is $88,000 \mathrm{ft}^{3}$ $\left(2,500 \mathrm{~m}^{3}\right)$.

PCB/TRU waste for shipment to WIPP will be characterized in accordance with the WIPP Waste Acceptance Criteria and the WIPP Waste Analysis Plan (Attachment B of

${ }^{1}$ Waste Isolation Pilot Plant RCRA [Resource Conservation and Recovery Act] Background Groundwater Quality Baseline Report, DOE/WIPP 98-2285, April 1998 
the HWFP). The owner/operators do not plan to take waste samples and analyze them to determine the exact concentration of PCBs in waste; rather, the owner/operators will assume that the nonliquid PCB/TRU waste contains PCBs in concentrations greater than 500 ppm and will handle it accordingly (40 CFR § 761.50[a][5]). Liquid PCB/TRU waste will not be received/disposed at WIPP as described in Attachment B of this initial report.

\subsection{GENERAL DESCRIPTION OF WASTE MATERIALS OTHER THAN PCBS (40 CFR § 761.75[c][1][vi])}

WIPP is designed to safely dispose of TRU waste. Waste materials destined for WIPP are the byproducts of nuclear weapons production and have been identified in terms of waste streams based on the processes that produced them. The types of wastes to be received at WIPP are described in detail in 40 CFR Part 191, Compliance Certification Application (CCA), and Attachment B of the HWFP.

Under the HWFP, each waste stream identified by generators is assigned to a Waste Summary Category (S3000—Homogeneous Solids, S4000—Soils/Gravel, and S5000-Debris Wastes) to facilitate waste characterization, and to reflect the final waste forms acceptable for WIPP disposal.

In addition, waste may be generated at the WIPP facility as a direct result of managing the waste materials received from the off-site generators. Such waste may be generated in either the WHB or the underground. This waste is referred to as "derived waste." All such derived waste will be placed in the rooms in HWDUs along with the TRU waste for disposal. Hazardous wastes generated at WIPP, through activities where contact with TRU waste does not occur, are characterized, placed in containers, and stored until they are transported off site for treatment and/or disposal at a permitted facility in accordance with 20.4.1.300 NMAC (incorporating 40 CFR Part 262).

\subsection{DISPOSAL FACILITY OPERATIONS PLAN (40 CFR § 761.75[c][1][vii])}

The management and disposal of PCBs at WIPP will be consistent with the disposal operations for TRU mixed wastes set forth in Modules II, III, and IV of the WIPP HWFP. A description of the plan for PCB/TRU waste receipt, confirmation, and emplacement is included in Attachment B of this initial report.

\subsection{FACILITY CONTINGENCY PLAN (40 CFR § 761.75[c][2])}

The response to spills, fires, or emergencies involving TRU mixed waste is described in the WIPP Contingency Plan included as Attachment $F$ of the WIPP HWFP. This plan describes detailed response actions to incidents involving TRU and TRU mixed waste, as well as memorandums of understanding and mutual aid agreements with local emergency response organizations and other mines in the area. A review by WIPP emergency management will be conducted to ensure the plan adequately addresses response actions to incidents involving PCB/TRU waste. 
In addition to the Contingency Plan, the owner/operators for WIPP also maintain several procedures for spill prevention, radiological and hazardous substance release response, environmental incident reporting, event response, and sampling to verify cleanup. These procedures are written in general terms to address emergency responses to radiological, hazardous substance, and PCB releases. These procedures have been developed to protect human health and the environment and to meet or exceed applicable environmental protection standards. Although no changes to these plans/ procedures are anticipated, each plan/procedure will be reviewed to ensure compliance with the requirements in 40 CFR Part 761, Subpart G, prior to receiving any PCB/TRU waste.

\subsection{FACILITY TRAINING PLAN (40 CFR § 761.75[C][2])}

The training for facility personnel is described in Attachment $\mathrm{H}$ of the WIPP HWFP. Attachment $\mathrm{H}$ describes the type and frequency of training received by WIPP facility personnel. Three WIPP training courses are described below with the proposed changes needed to address the safe storage and disposal of PCB/TRU waste.

Each employee at the WIPP facility is trained and given instruction through a General Employee Training (GET) course. GET is provided to new employees and contractors to familiarize personnel with WIPP operations, rules of conduct, methods of communications, hazard recognition, safety culture, and other information as necessary. This training is designed to help employees recognize the various alarm signals, the significance of each, and the proper response to each. WIPP facility employees and site visitors are required to comply with directions from emergency personnel and alarm system notifications and to follow emergency evacuation routes and exits. GET also instructs employees in recognition of and adherence to postings and warnings. Information concerning the hazards of PCBs and posted warnings will be added to this training.

In addition, Hazardous Waste Worker and Hazardous Waste Responder training is provided in accordance with 29 CFR § 1910.120(p) and 40 CFR § 264.16. These courses are designed to ensure that workers understand the hazards associated with waste received and generated at the WIPP site. In addition, these courses instruct personnel on how to handle wastes safely under normal and emergency conditions and when to implement the Contingency Plan and emergency response procedures. These training courses will be modified to incorporate additional information concerning the hazards associated with PCBs.

\subsection{LOCAL, STATE, OR FEDERAL PERMITS OR APPROVALS (40 CFR § 761.75[c][1][viii])}

Attachment $\mathrm{C}$ of this initial report lists the local, state, and federal permits and approvals previously obtained. 


\subsection{SCHEDULES OR PLANS FOR COMPLYING WITH THE APPROVAL REQUIREMENTS (40 CFR § 761.75[C][1][ix])}

WIPP is currently permitted and operational for the receipt of $\mathrm{CH}$ TRU and $\mathrm{CH}$ TRU mixed wastes with most of the infrastructure and operations described in this initial report in place. Therefore, only changes to specifically address PCB waste management will be necessary. The following identify the types and schedule for completion of these changes/activities:

Emergency planning: No changes are anticipated in the emergency response plans/procedures, a review will be conducted to confirm the adequacy of these plans/procedures prior to making amendments to the training courses. Lessons learned from this review will be incorporated into the training courses, procedures, and/or plans. If changes are determined to be necessary to the Contingency Plan, these changes will be addressed in the HWFP modification to remove the current restriction on PCB wastes.

Training: General Employee, Hazardous Waste Worker, and Hazardous Waste Responder training courses will be amended to address PCBs. These amendments will be completed prior to receipt of PCB disposal approval. Employees will begin receiving this training following the approval of these amendments.

Area postings: PCBs warnings will be posted at the radiological access control points in the WHB and underground HWDU in accordance with 40 CFR $\S 761.45(a)(10)$ after receipt of the approval and prior to receiving PCB waste.

Record keeping: Receipt/disposal of PCB/TRU wastes will require several additional records as described in Attachment B of this initial report. These records will be maintained beginning with the receipt of the first drum containing PCBs. 
Attachment A

General Site Plans and Design Drawings 


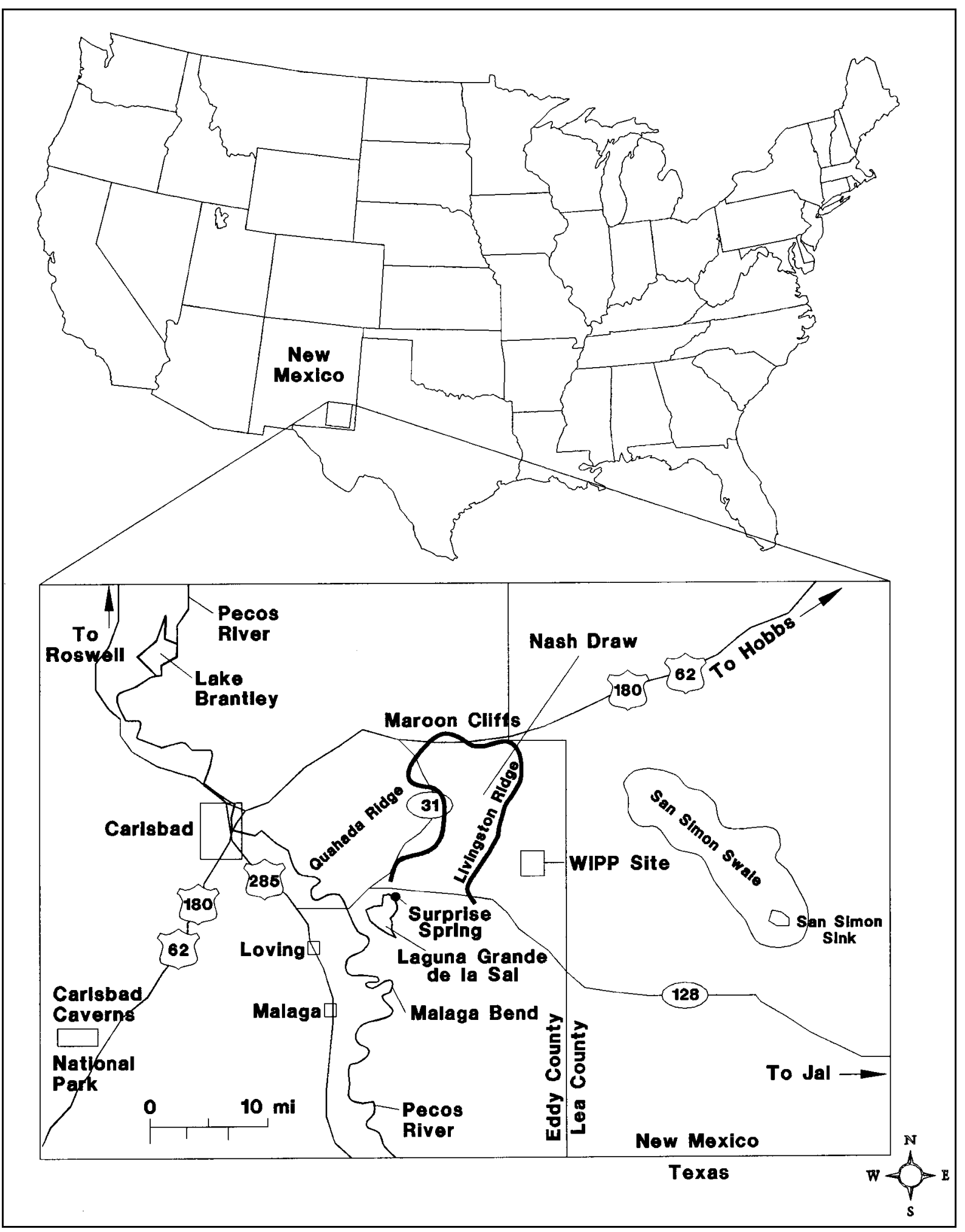

Figure 1. WIPP Facility Location 
Waste Isolation Pilot Plant Initial Report for PCB Disposal Authorization DOE/WIPP 02-3196

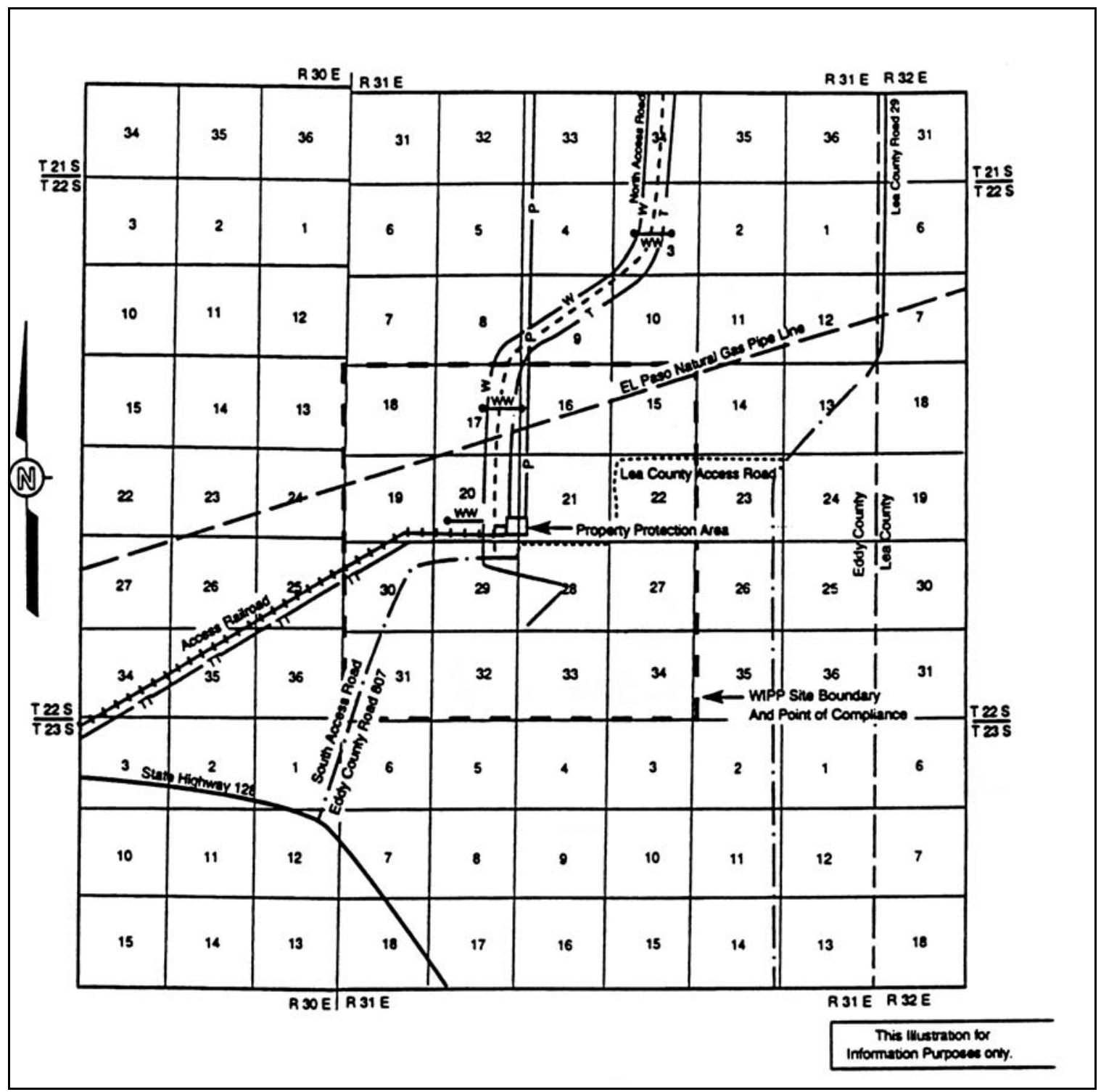

Figure 2. WIPP Facility Boundaries 
Waste Isolation Pilot Plant Initial Report for PCB Disposal Authorization DOE/WIPP 02-3196

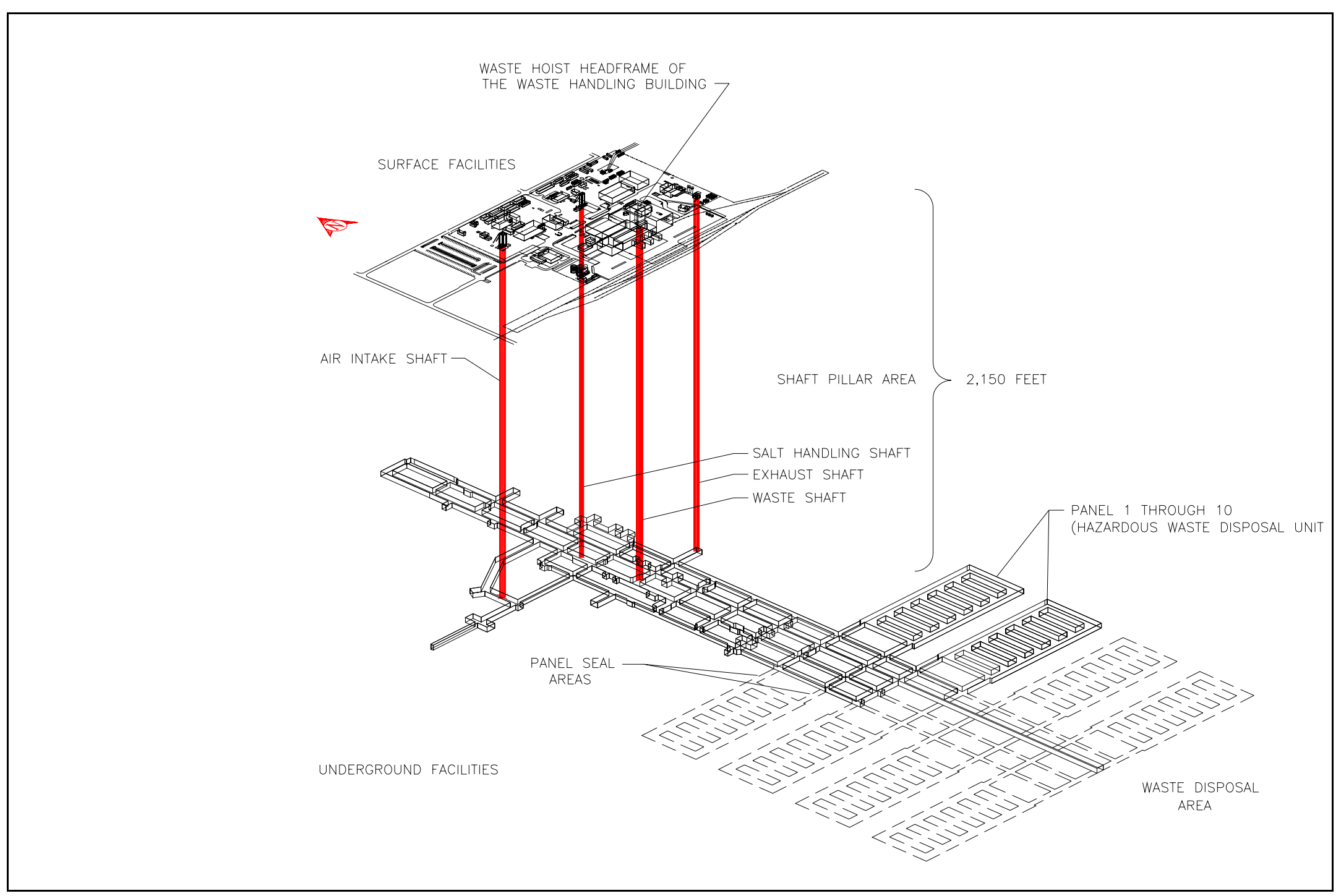

Figure 3. Spatial View of WIPP Facilities

Page 14 of 43 


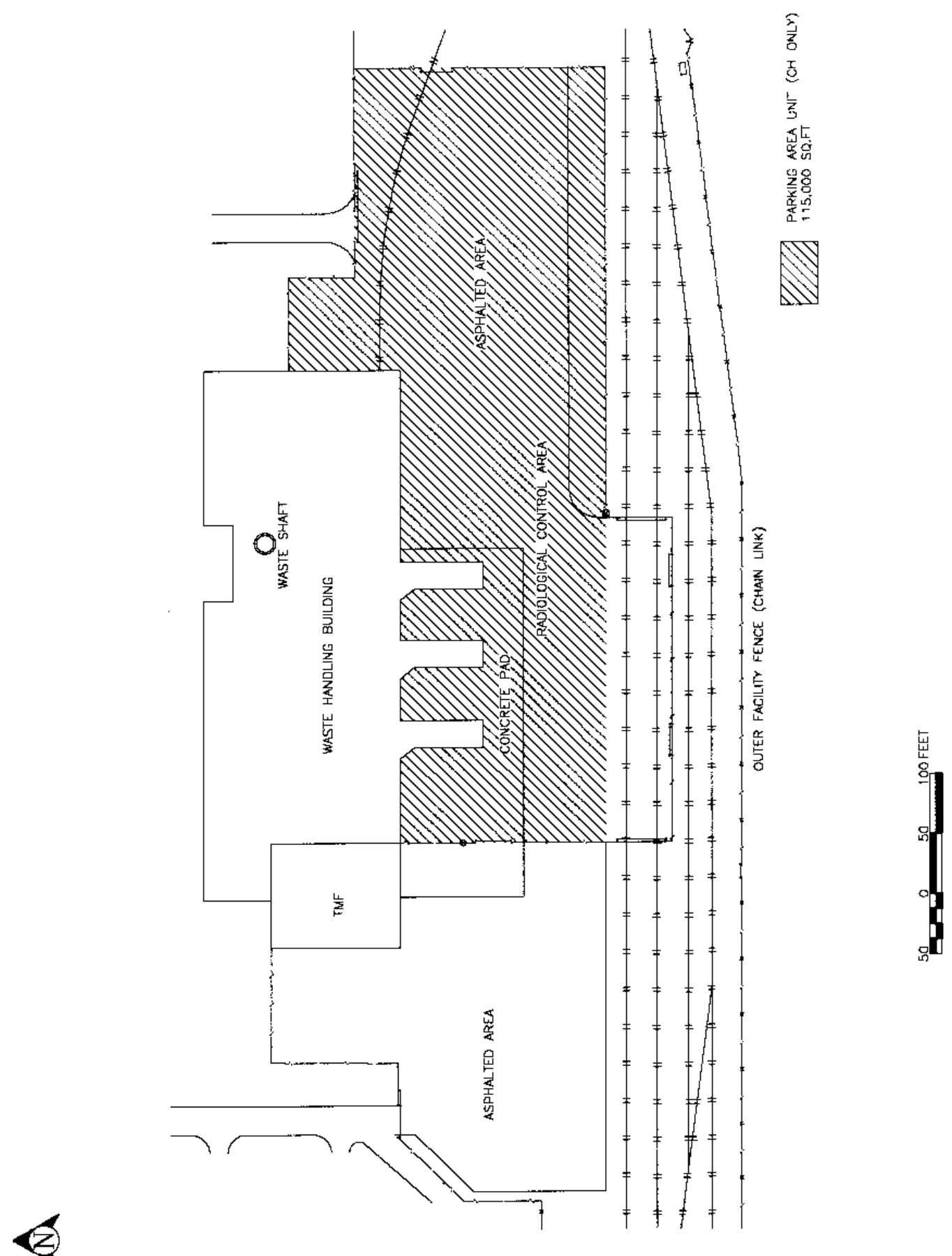

Figure 4. Parking Area-Container Storage Unit 


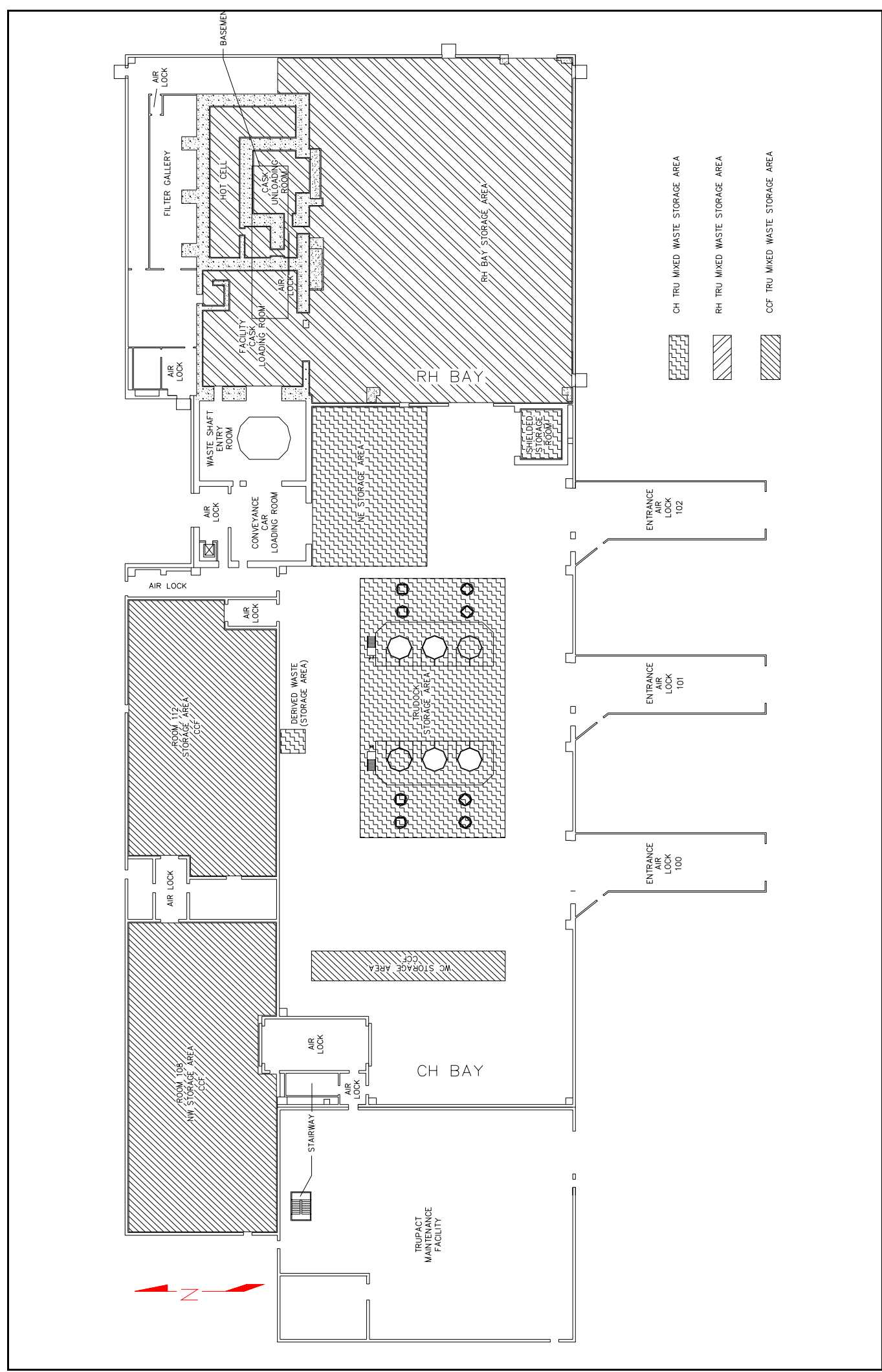

Figure 5. Waste Handling Building-Container Storage Unit 
Waste Isolation Pilot Plant Initial Report for PCB Disposal Authorization DOE/WIPP 02-3196

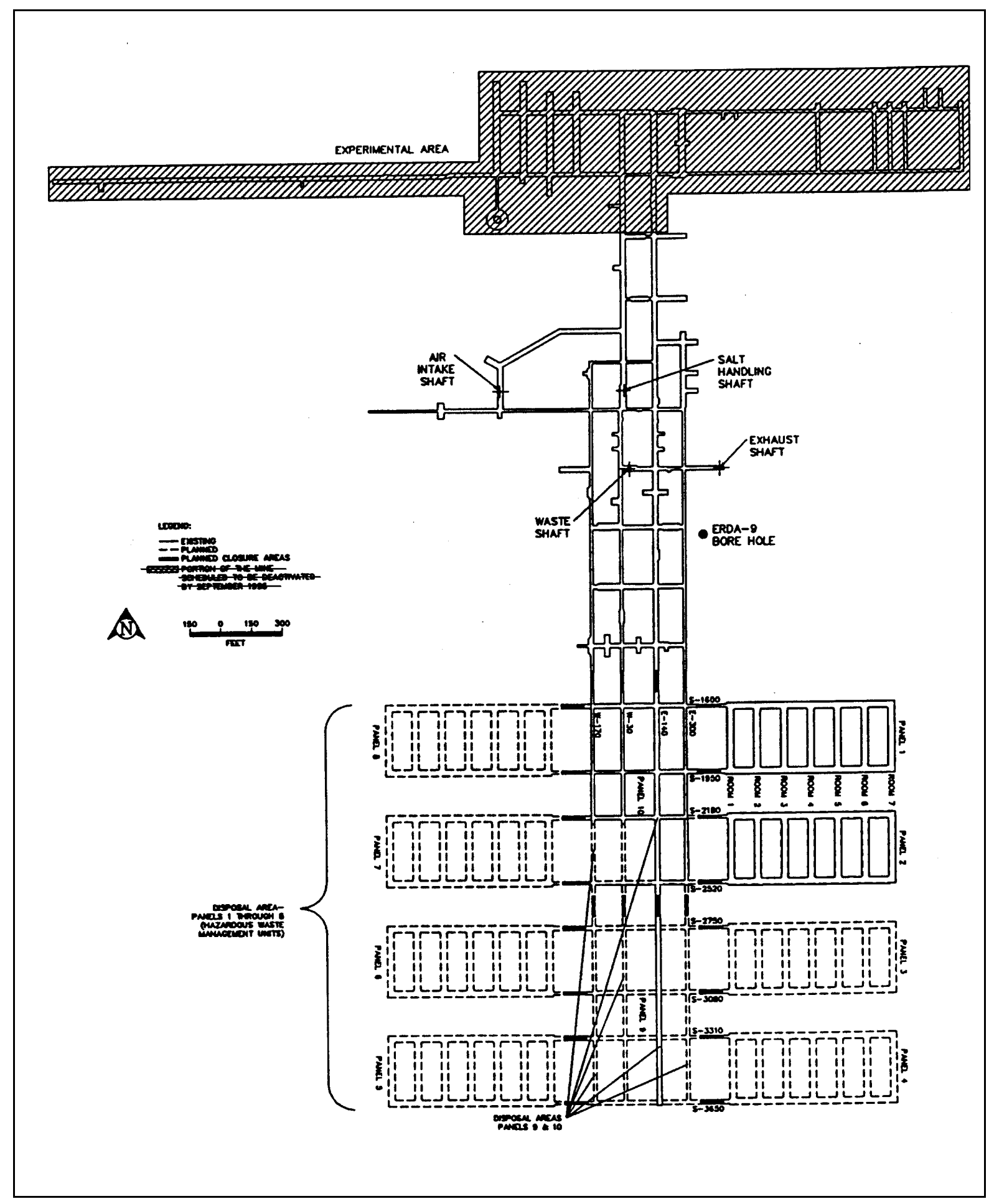

Figure 6. Underground Repository - Waste Disposal Area 
Waste Isolation Pilot Plant Initial Report for PCB Disposal Authorization DOE/WIPP 02-3196
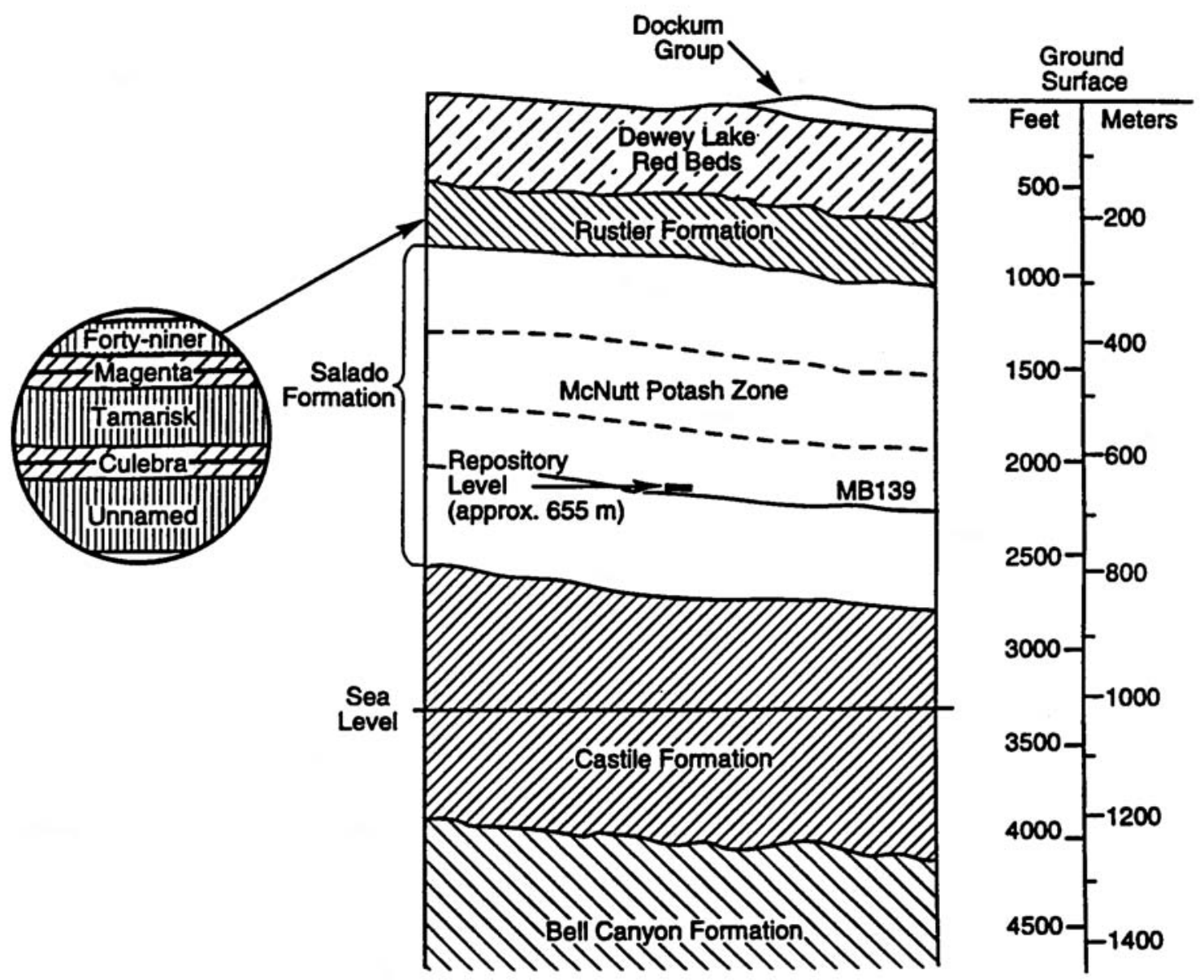

TRA-6121-2520

Figure 7. Generalized Stratigraphy of the WIPP Site Showing Repository Level 


\section{Attachment B}

Engineering Report Describing the Manner in Which WIPP Complies with the Requirements for Chemical Waste Landfills 


\section{ENGINEERING REPORT}

\section{WIPP Compliance with Technical Standards for Chemical Waste Landfill Disposal}

\section{Introduction}

This engineering report is being submitted pursuant to Title 40 Code of Federal Regulations (CFR) $§ 761.75$ (c)(1)(iii) to demonstrate compliance with the applicable technical requirements for chemical waste landfills specified in 40 CFR $\S$ 761.75(b). While these regulations do not specifically provide for a deep geologic repository, such as the Waste Isolation Pilot Plant (WIPP), this section demonstrates how WIPP meets or exceeds these applicable technical requirements.

On May 18, 1998, the Environmental Protection Agency (EPA) certified that WIPP complies with the radioactive waste disposal regulations set forth in Subparts B and C of 40 CFR Part 191 and the site-specific WIPP compliance criteria at 40 CFR Part 194. The performance assessment, used by the owner/operator to comply with the disposal regulations, demonstrates that the waste will not migrate from the repository for 10,000 years. In addition, the owner/operators have obtained a Hazardous Waste Facility Permit (HWFP) from the New Mexico Environment Department (NMED) for the disposal of transuranic (TRU) mixed waste at WIPP.

This report also contains requests for waivers pursuant to 40 CFR $\S 761.75(\mathrm{c})(4)$ to three of the technical requirements: Hydrologic Conditions (40 CFR § 761.75[b][3]), Monitoring Systems (40 CFR § 761.75[b][6]), and Leachate Collection (40 CFR § 761.75[b][7]).

\section{Soils (40 CFR § 761.75[b][1])}

The WIPP disposal area is located in a thick, relatively impermeable formation of salt known as the Salado Formation (Attachment A, Figure 7). The Salado Formation consists mainly of halite and anhydrite. A considerable amount of information about the hydraulic properties of halite has been collected through field and laboratory experiments. Twenty-two hydraulic tests have been performed in impure halite, and two in pure halite. Interpreted permeabilities using a Darcy-flow model vary from $1 \times 10^{-23}$ to $4 \times 10^{-18}$ square meters for impure halite intervals. The converted values ${ }^{2}$ for the Darcy-flow permeability values to the unit of measures employed to define conductance standards are represented below:

$$
\begin{aligned}
& 1 \times 10^{-23} \mathrm{~m}^{2}=6 \times 10^{-15} \mathrm{~cm} / \mathrm{s} \\
& 4 \times 10^{-18} \mathrm{~m}^{2}=2 \times 10^{-9} \mathrm{~cm} / \mathrm{s}
\end{aligned}
$$

\footnotetext{
${ }^{2}$ WIPP Compliance Certification Application, § 2.2.1.3
} 
These values are converted from permeability to conductivity and are well below the required permeability value of $1 \times 10^{-7} \mathrm{~cm} / \mathrm{sec}$ in $40 \mathrm{CFR} \S 761.75(\mathrm{~b})(1)$ (ii) for soils lining a chemical waste landfill.

\section{Synthetic Membrane Liners (40 CFR § 761.75[b][2])}

Synthetic membrane liners are required if the Regional Administrator determines that such a liner is needed to provide at least a permeability equivalent to the soils requirement in 40 CFR $\S 761.75(\mathrm{~b})(1)$. As indicated above, the low permeability of the Salado Formation exceeds this requirement; therefore, it is not anticipated that a synthetic membrane liner would be required.

\section{Hydrologic Conditions (Waiver Request to 40 CFR § 761.75[b][3])}

A waiver is hereby requested to the requirement for hydrologic conditions pursuant to 40 CFR $\S 761.75(\mathrm{c})(4)$. This waiver is necessary because WIPP does not meet the requirement for the bottom of the landfill to be at least fifty feet above the historical high groundwater table. The WIPP repository is situated in the thick, relatively impermeable Salado Formation salt beds 2,150 ft $(655 \mathrm{~m})$ below the ground surface and is wellisolated from the hydrologic environment by adjacent evaporite strata. However, the stated purpose of this requirement 40 CFR $\S 761.75(b)(3)$ is to ensure that no hydraulic connection exists between the site and standing or flowing surface water. Compliance with this stated purpose was documented in the WIPP Compliance Certification Application and supported by numerous studies of the geohydrologic conditions in the area around the WIPP site. ${ }^{3}$ These studies identified three principal water-bearing zones above the disposal area and one below. The zones above the Salado Formation are the contact between the Rustler and Salado Formations and the Culebra and Magenta Dolomite Members of the Rustler Formation (Attachment A, Figure 7). The zone below the Salado Formation consists of channel sandstones in the Bell Canyon Formation. These studies indicated that these water-bearing zones are effectively isolated from the disposal area by relatively impermeable evaporite strata. Therefore, a waiver to this requirement will not present an unreasonable risk to human health or the environment.

\section{Flood Protection (40 CFR § 761.75[b][4])}

Pursuant to 40 CFR $\S 761.75(b)(4)$, the landfill site must be protected from flood water. The WIPP repository (landfill site) is situated in the thick, relatively impermeable Salado Formation salt beds, and is well-isolated from flood waters. In addition, the WIPP site mean surface elevation is approximately $400 \mathrm{ft}(122 \mathrm{~m})$ above the 100-year floodplain. ${ }^{4}$ The land areas around the surface buildings are designed to minimize erosion. Runoff

\section{Structures}

${ }^{3}$ CCA, Appendix GCR, Geological Characterization Report

${ }^{4}$ WIPP SAR, DOE/WIPP-95-2065 Rev. 3 and CCA, Chapter 3.1.3, Surface 
water is diverted as necessary from the buildings, tracks, or roads and returned to the natural drainage path.

There are no major surface-water bodies within $5 \mathrm{mi}(8 \mathrm{~km})$ of the site, and the nearest river, the Pecos River, is approximately $15 \mathrm{mi}(24.14 \mathrm{~km})$ away. The general ground elevation in the vicinity of the surface facilities (approximately 3,400 ft [1,036 m] above mean sea level) is about $500 \mathrm{ft}(152 \mathrm{~m})$ above the riverbed, and $400 \mathrm{ft}(122 \mathrm{~m})$ above the 100-year floodplain. Protection from flooding or ponding caused by probable maximum precipitation (PMP) events is provided by the diversion of water away from the WIPP facility by a system of peripheral interceptor diversions. Additionally, grade elevations of roads and surface facilities are designed so that storm water will not collect on the site under the most severe conditions. Repository shafts are elevated at least 6 in. $(15.2 \mathrm{~cm})$ to prevent surface water from entering the shafts. The floor levels of all surface facilities are above the levels for local flooding due to PMP events.

Facilities at the WIPP site have been constructed to contain or control storm water discharges; these include retention basins and storm water diversion berms. The site's water tanks (two 180,000 gal [681,354 L]) are located at the southwest corner of the property protection area, the topography of the site includes a sloping terrain to this corner of the site. There is a catch basin to the west of the water tanks, which is designed with adequate capacity (approximately 4.5 acres; approximately 0.25 acre/ft depth for failure of both tanks) to hold runoff from a failure of the water tanks.

The owner/operators worked closely with the EPA Region VI Storm Water Section and the NMED Groundwater and Surface Water Bureaus to evaluate compliance alternatives. Meetings were conducted to evaluate retention basin designs to ensure that retention basins were sized, designed, and constructed to meet NMED design criteria. Runoff coefficients were calculated using both the EPA and NMED runoff calculation guidelines. Because the NMED guidelines are more stringent, they were chosen for calculating storm water runoff from the facility. The NMED requires that two consecutive 10-year/24-hour storm events be used to calculate site runoff coefficients. These calculations were then used to develop engineering designs for all retention basins. Engineering studies were conducted to evaluate storm water flow patterns and to demonstrate that the existing WIPP storm water swale system has adequate capacity to accommodate calculated peak flows. The owner/operators focused on locating retention basins in natural depressions to maximize storage capacity and minimize surface impacts.

Note: 10-year/24-hour storm event $=3.2$ inches.

Two consecutive 10-year/24-hour storm event $=6.4$ inches. 100 -year/24-hour storm event $=5.0$ inches.

\section{Topography (40 CFR § 761.75[b][5])}

Typically, landfills are located in an area of low to moderate relief to minimize erosion and to help prevent landslides or slumping. The WIPP surface facilities are located in an area of low to moderate relief. However, the WIPP repository is located 2,150 $\mathrm{ft}$ 
below the surface. This location prevents erosion or landslides; however, the repository is closely monitored and maintained to prevent any potential roof fall or ground spalling events.

\section{Monitoring Systems (Waiver Request to 40 CFR § 761.75[b][6])}

A waiver is hereby requested to the requirement for sampling both groundwater and surface water pursuant to $40 \mathrm{CFR} \S 761.75(\mathrm{c})(4)$. This waiver is being requested due to the lack of surface waters at or near the WIPP facility and the lack of hydraulic connection between the waste repository and the groundwater. ${ }^{5}$ However, the owner/ operators currently monitor surface (Pecos River and Brantley Lake) and groundwater for radioactive and hazardous constituent releases in accordance with Module $V$ of the HWFP. ${ }^{6}$ The monitoring parameters include target analytes chosen based upon their relative concentration in the repository and their ability to migrate. Detection of these analytes could indicate a potential release of waste and would be subject to reporting and investigation requirements identified in Module $V$ of the HWFP. Baseline surface and groundwater sampling around the WIPP facility indicated that there were no measurable PCBs in either. ${ }^{7}$ Therefore, a waiver to this requirement will not present an unreasonable risk to human health or the environment.

\section{Leachate Collection (Waiver Request to 40 CFR § 761.75[b][7])}

A waiver is hereby requested to the requirement for leachate collection and monitoring pursuant to 40 CFR $\S 761.75$ (c)(4). This waiver is being requested due to the geologic structure of the repository and the low presence of liquids necessary to form leachates. The repository is located in a salt layer with very low permeability and transmissivities as demonstrated by the EPA certification of the WIPP's compliance with the long-term disposal standards for radioactive TRU waste. Compliance with these requirements as codified in 40 CFR Part 191, Subparts B and C, demonstrated that waste will not migrate from the repository for 10,000 years. ${ }^{8}$ Based on the lack of liquids, no leachate is anticipated to be formed. Therefore, a leachate collection and monitoring system would not be effective, and a waiver to this requirement will not present an unreasonable risk to human health or the environment.

${ }^{5}$ Compliance Certification Application

${ }^{6}$ WIPP Hazardous Waste Facility Permit, October 27, 1999, Permit No. NM4890139088-TSDF

${ }^{7}$ Waste Isolation Pilot Plant RCRA Background Groundwater Quality Baseline Report, DOE/WIPP 98-2285, April 1998

${ }^{8}$ Compliance Certification Application 


\section{Disposal Facility (Chemical Waste Landfill) Operations Plan (40 CFR § 761.75[b][8])}

The management and disposal of PCBs at WIPP will be consistent with the operations set forth in Modules II, III, and IV of the WIPP HWFP. WIPP will be operated in accordance with the HWFP, including record keeping (Modules I and II), Hazardous Waste Disposal Units (HWDU) mining and closure (Attachments I and M2), waste segregation burial coordinates (Attachment $B$ ), vehicle and equipment movement and use of roadways (Attachment $G$ ), environmental emergency contingency plans (Attachment F), security (Attachment $C$ ), and unauthorized waste placements (Attachment B).

The chemical compatibility of PCBs with the types and quantities of wastes to be received at WIPP has been reviewed for potential incompatibilities using EPA guidelines. ${ }^{9}$ PCBs have been determined not to be incompatible with other wastes managed and disposed at WIPP; therefore, no waste segregation will be necessary. Changes to the types of wastes being received will be reviewed for compatibility prior to acceptance at WIPP.

A description of the process for waste processing is included below. Descriptions of the $\mathrm{RH} \mathrm{PCB} / \mathrm{TRU}$ waste handling and the central confirmation facility processes are also described. These two processes are subject to "conditional approval" as described in Sections 1.0 and 3.3 of this initial report.

\section{$\underline{\text { Transportation }}$}

The owner/operators have contracts in place to provide safe transportation of wastes from the DOE generator/storage sites (e.g., Idaho National Engineering and Environmental Laboratory, Rocky Flats Environmental Technology Site, Los Alamos National Laboratory) to the WIPP facility. Under these contracts, the transportation companies provide dedicated vehicles and personnel for the shipment of wastes. This provides for well-trained and knowledgeable drivers who are capable of safely transporting waste to the WIPP facility. After arrival at WIPP, external radiological surveys, security checks, and shipping documentation reviews are performed and the shipping containers are parked in the Parking Area Unit located south of the Waste Handling Building (WHB) (described below).

Wastes transported to the WIPP site by truck are shipped in Type B shipping containers licensed by the Nuclear Regulatory Commission (NRC) with various configurations of containers meeting Department of Transportation (DOT) Type A drums and containers. Under this authorization, the owner/operators request to use any approved Type B

\footnotetext{
9"A Method for Determining the Compatibility of Hazardous Wastes"; EPA-600/2-80-076; April 1980; R. A. Carnes, H. K. Hatayama, J. J. Chen, E. R. de Vera, R. D. Stephens, and D. L. Storm; California Department of Health Services, Berkeley, California.
} 
shipping containers. Under 10 CFR $\S 71.73(c)$, Type B containers are subjected to rigorous testing (e.g., drop, puncture, and burn tests) to ensure that they can withstand hypothetical accident conditions as required. The following is the list of licensed Type B containers currently used for the transportation of TRU wastes to WIPP:

- $\quad$ TRUPACT-II (CH [contact-handled] waste shipments only)

- $\quad$ HalfPACT ( $\mathrm{CH}$ waste shipments only)

- $\quad$ RH-TRU 72B (RH waste shipments only)

- $\quad$ CNS 10-160B (RH waste shipments only)

Information concerning these containers (e.g., design, capacity, certification, etc.) is available at http://www.wipp.ws/library/caolib.htm\#RCRA.

Surface Facility Descriptions:

The following are descriptions of the facilities that will be used to safely manage and store PCB/TRU wastes for disposal in the underground repository.

Parking Area Unit (south of the WHB) is used for storage of waste containers within sealed shipping containers (Attachment A, Figure 4). The Parking Area Unit will provide storage space for $1,591 \mathrm{ft}^{3}\left(45 \mathrm{~m}^{3}\right)$ of $\mathrm{CH}$ PCB/TRU waste. Secondary containment and protection of the waste containers are provided by the sealed shipping containers. Waste placed in the Parking Area Unit remains sealed in shipping containers at all times while in this area.

The WHB is designed to meet DOE design and associated quality assurance requirements. The WHB is the surface facility where $\mathrm{PCB} / T R U$ waste handling activities will take place. The concrete floors are sealed with a coating that is sufficiently impervious to the chemicals in PCB/TRU waste. This area is permitted under the HWFP as the WHB Unit with several areas within the WHB (e.g., northeast storage area, shielded storage area) designated to store TRU and TRU mixed waste (Attachment A, Figure 5). Approval of the central confirmation facility and/or the RH $\mathrm{PCB} / \mathrm{TRU}$ waste requests will add additional storage areas (e.g., northwest storage area, waste container storage area, Hot Cell storage area, cask unloading room) within the WHB Unit. Pursuant to 40 CFR $\S 761.65(b)(2)$ (iii), these areas will be used to store $\mathrm{PCB} / \mathrm{TRU}$ waste designated for disposal at WIPP. The $\mathrm{CH}$ Bay, $\mathrm{RH}$ Bay, and central confirmation facility are located within the WHB.

The $\mathrm{CH}$ Bay (Attachment A, Figure 5) is the area within the WHB designed for the management and storage of $\mathrm{CH}$ TRU and $\mathrm{CH}$ PCB/TRU wastes. This bay currently includes several storage areas clearly marked to indicate the lateral limits of the storage areas. These areas include the northeast storage area with a maximum capacity of $1,856 \mathrm{ft}^{3}\left(52.6 \mathrm{~m}^{3}\right)$; the shielded storage area with a maximum capacity of $256 \mathrm{ft}^{3}$ $\left(7.5 \mathrm{~m}^{3}\right)$; and the derived waste storage area with a maximum capacity of $66.3 \mathrm{ft}^{3}$ $\left(1.88 \mathrm{~m}^{3}\right)$. Approval of the central confirmation facility request will increase the area of the $\mathrm{CH}$ Bay. In addition, three storage areas will be added: the northwest storage area, the waste container storage area, and the Room 112 storage area. 
The RH Bay (Attachment A, Figure 4) is the area within the WHB designed for the management and storage of RH TRU and RH PCB/TRU wastes. This bay includes several storage areas: the RH bay, the Cask Unloading Room, the Hot Cell, the Transfer Cell, and the Facility Cask Loading Room.

\section{General Operations}

Unless otherwise indicated, the following conditions will apply to $\mathrm{CH}$ PCB/TRU waste, central confirmation facility, and RH PCB/TRU waste operations:

Container management: Containers will be managed in a manner that minimizes the probability of spills or leaks. Containers are required to be closed at all times, except as necessary to add or remove waste, remove a prohibited item, or perform a Waste Analysis Plan required visual examination. If a primary waste container is not in good condition, the container will be overpacked. The overpack container will be labeled with the same information as the primary container.

Discrepant payloads: If discrepant payloads are noted, they will be placed either in a storage area of the WHB on a facility pallet or inside a shipping container, depending on when the discrepancy is discovered.

Aisle space: Adequate aisle space is maintained in all WHB Unit PCB/TRU waste storage areas to allow unobstructed movement of fire-fighting personnel, spill-control equipment, and decontamination equipment that would be used in the event of an offnormal event.

Off-normal events: Off-normal events could interrupt normal operations in the waste management process line. These off normal events fall into the following categories: waste management system equipment malfunctions; waste shipments with unacceptable levels of surface contamination; hazardous waste manifest discrepancies that are not immediately resolved; and/or a suspension of emplacement activities for regulatory reasons. Shipments of waste from the generator/storage sites may be stopped if an off-normal event warrants.

Derived waste: Wastes may be generated as a direct result of managing PCB/TRU wastes. These derived wastes will be assumed to have the same properties as the waste from which it was derived and will be managed in containers within the derived waste storage area. Derived waste containers are kept closed at all times unless waste is being added or removed. Derived wastes will be disposed in the same manner as other wastes received.

Training: Waste handling personnel are thoroughly trained in the safe use of waste handling and transport equipment. The training includes both classroom training and on-the-job training. 


\section{$\underline{\mathrm{CH} \text { Surface Operations }}$}

$\mathrm{CH}$ PCB/TRU wastes will be staged in the Type B shipping containers used to transport the wastes in the Parking Area Unit. The Type B shipping containers will then be received through one of three air-lock entries to the $\mathrm{CH}$ Bay of the WHB Unit. Inside the $\mathrm{CH}$ Bay, overhead cranes at one of the TRUPACT-II docks (TRUDOCKs) will be used to open and unload the Type B shipping containers. The TRUDOCKs are within the TRUDOCK storage area of the WHB Unit (Attachment A, Figure 5).

The cranes are rated to lift the shipping container lids and the shipping container contents. The cranes are designed to remain on their tracks and hold their load even in the event of a design-basis earthquake. Upon receipt and removal of $\mathrm{CH} P C B / T R U$ waste containers from the shipping containers, the waste containers will be visually inspected for physical damage (severe rusting, apparent structural defects, signs of pressurization, etc.) and leakage to ensure that they are in good condition prior to storage. Waste containers will also be checked for external surface radiological contamination. Waste containers may be stored in this area in the shipping container (with or without the shipping container lids removed). Waste containers inside the shipping container will not be inspected until they are removed.

Once unloaded from the shipping containers, waste containers will be placed in one of two positions on the facility pallet or on a containment pallet. The waste containers will be stacked, as they arrive, on facility pallets (one- or two-high, depending on weight considerations). Pallets of waste can be stored at the TRUDOCKs or relocated to the northeast storage/shielded storage areas of the WHB Unit for normal storage.

The following are the major pieces of equipment that will be used to manage $\mathrm{CH}$ $\mathrm{PCB} / \mathrm{TRU}$ waste in the container storage units:

TRUDOCK: Each unloading dock inside the WHB is designed to accommodate up to two shipping containers. The TRUDOCK functions as a work platform, providing $\mathrm{PCB} / \mathrm{TRU}$ waste handling personnel easy access to the container during unloading operations.

Forklifts: Used to transfer the shipping containers into the WHB Unit and to transfer palletized $\mathrm{CH}$ PCB/TRU waste containers to the conveyance loading car. Another forklift will be used for general-purpose transfer operations. This forklift has attachments and adapters to handle individual PCB/TRU waste containers, if required.

Overhead bridge crane: Used with a specially designed lift fixture for disassembly of the shipping containers. Separate lifting attachments have been specifically designed to accommodate Standard Waste Boxes (SWB) and Ten-Drum Overpacks (TDOP). The lift fixture, attached to the crane, has built-in level indicators and two counterweights that can be moved to adjust the center of gravity of unbalanced loads and to keep them level. 
Facility pallet: fabricated steel unit designed to support 7-packs of drums, SWBs, TDOPs, or groups of overpack drums, and has a rated load of $25,000 \mathrm{lb}(11,430 \mathrm{~kg})$. The facility pallet accommodates up to four 7-packs of drums or four SWBs (in two stacks of two units), two TDOPs, two groups of overpack drums (maximum of four drums per group), or any combination thereof.

Conveyance loading car: a vehicle that operates on rails. It is designed with a flat bed that has adjustable height capability and is used to transfer the facility pallets on or off the pallet support stands in the waste hoist conveyance.

\section{Central Confirmation Facility Operations}

Under the central confirmation facility modification, storage of waste requiring confirmation of generator/storage site waste characterization may be moved to and stored at the northwest storage area (Room 108), waste container storage area, and/or Room 112.

When the central confirmation facility permit modification is approved, $\mathrm{CH}$ PCB/TRU waste that has not undergone confirmation will be transferred from the facility pallet to a containment pallet for storage. Up to eight drums, or $6,000 \mathrm{lb}(2,720 \mathrm{~kg})$, may be placed on a containment pallet. These wastes will be transferred between storage areas until confirmation in accordance with the WIPP Waste Analysis Plan is complete and the waste containers are certified by the Site Project Manager. This process may take up to one year to complete due to HWFP requirements for sampling and analysis. The certified containers will then be transferred and stored on a facility pallet prior to transport to the underground.

\section{$\underline{\mathrm{RH} \text { Surface Operations }}$}

RH PCB/TRU wastes will be staged in the Type B shipping casks used to transport the wastes containers in the Parking Area Unit. The Type B shipping cask will then be received through a set of double doors on the east side of the WHB. The RH Bay houses the cask transfer car. The RH Bay is served by an overhead bridge crane used for shipping cask handling and maintenance operations. All storage in the RH Bay will occur in the RH shipping casks. The casks will be stored either on the trailer or the cask transfer car. The storage will occur after the trailer containing the cask is moved into the RH Bay and prior to the cask being moved into the Cask Unloading Room to stage the waste for disposal operations.

The Cask Unloading Room provides for transfer of the RH shipping cask to the Transfer Cell. Waste containers in RH shipping casks that need to be put in canisters at WIPP can be transferred to the Hot Cell from the Cask Unloading Room. Storage in the Cask Unloading Room will occur in the RH shipping casks. Storage in this area typically will occur at the end of a shift or in an off-normal event that results in the suspension of a waste handling evolution. 
The Hot Cell is a concrete-shielded room in which drums of RH PCB/TRU waste will be transferred remotely from the shipping cask, staged in the Hot Cell, and loaded into a canister. The loaded canister will then be lowered from the Hot Cell into the Transfer Cell shuttle car containing a shielded insert. Waste will be stored in the Hot Cell in either drums or canisters. Drums will be stored either on the drum carriage unit that is removed from the shipping cask or in a canister located in one of the specially designed canister sleeves designed for holding a single canister.

The Transfer Cell houses the Transfer Cell shuttle car, which will move the RH shipping cask or shielded insert into position for transferring the canister to the facility cask. Storage in this area typically will occur at the end of a shift or in an off-normal event that results in the suspension of a waste handling evolution.

The Facility Cask Loading Room provides for transfer of a canister to the facility cask for subsequent transfer to the waste hoist and to the underground HWDUs. The Facility Cask Loading Room also functions as an air lock between the waste shaft and the Transfer Cell. Storage in this area typically occurs at the end of a shift or in an offnormal event that results in the suspension of a waste handling evolution.

The following are major pieces of equipment that will be used to manage RH PCB/TRU mixed waste.

RH Bay overhead bridge crane: In the RH Bay, an overhead bridge crane will be used to lift the shipping cask from the trailer and place it on the cask transfer car. It also will be used to remove the impact limiters from the shipping casks and the outer lid of the $\mathrm{RH}$ shipping cask.

Cask lifting yoke: The lifting yoke is a lifting fixture that attaches to the overhead crane and is designed to lift and rotate the $\mathrm{RH}$ shipping cask onto the transfer car.

Cask transfer car: The cask transfer car, a self-propelled, rail-guided car, will transport the shipping cask between the RH Bay and the Cask Unloading Room.

Grapple hoist: A grapple hoist will be used to hoist the canister from the Transfer Cell shuttle car into the facility cask.

Facility cask: The facility cask body consists of two concentric steel cylinders. The annulus between the cylinders is filled with lead, and gate shield valves are located at either end. The canister will be placed inside the facility cask for shielding during canister transfer from the surface to the underground HWDU for emplacement.

Facility cask transfer car: The facility cask transfer car is a self-propelled rail car that will be used to move the facility cask between the Facility Cask Loading Room and the shaft station underground.

Hot Cell bridge crane: The Hot Cell overhead bridge crane, outfitted with a rotating block and the facility grapple, will be used to lift the shipping cask lid and the drum 
carriage units from the shipping cask into the Hot Cell. The Hot Cell crane also will be used to lift the empty disposal canisters into place within the Hot Cell and to lower loaded canisters into the Transfer Cell.

Overhead powered manipulator: The overhead powered manipulator will be used in the Hot Cell to lift individual drums from the drum carriage unit and lower each drum into the disposal canister.

Manipulators: There are two sets of fixed manipulators in the Hot Cell. The manipulators will collect swipes of drums as they are being lifted from the drum carriage unit and transfer the swipes to the shielded material transfer drawer.

Shielded material transfer drawer: The shielded material transfer drawer will be used to transfer swipe samples obtained by the fixed manipulators to the Hot Cell Gallery for radiological counting.

Transfer Cell shuttle car: The Transfer Cell shuttle car will position the canister under the Facility Cask Loading Room port.

Cask Unloading Room crane: The Cask Unloading Room crane will lift and suspend the $\mathrm{RH}$ Cask or shielded insert from the transfer car and lower the cask or shielded insert into the Transfer Cell shuttle car.

\section{Underground Operations}

Operations consist of receiving $\mathrm{CH}$ PCB/TRU waste shipping containers, unloading and transporting the waste containers to the underground HWDUs, emplacing the waste in the underground HWDUs, and closing of the underground HWDUs in compliance with applicable state and federal regulations.

The WIPP geologic repository is mined within a 2,000-foot (ft) (610-meter [m])-thick bedded-salt formation called the Salado Formation. The underground HWDUs (miscellaneous units) are located 2,150 ft $(655 \mathrm{~m})$ beneath the ground surface. $\mathrm{PCB} / \mathrm{TRU}$ waste management activities underground will be confined to the southern portion of the 120 -acre (48.5 hectares) mined area during the Disposal Phase.

Four shafts connect the underground area with the surface. The waste shaft headframe and hoist are within the WHB and are used to transport containers of PCB/TRU waste, equipment, and materials to the repository horizon. The waste hoist is used to transport personnel and materials. The air intake shaft provides ventilation to all areas of the mine except for the waste shaft station. The salt handling shaft is used to hoist mined salt to the surface and serves as the principal personnel transport shaft. The exhaust shaft serves as a common exhaust air duct for all areas of the mine.

The HWDUs identified as panels 1 through 3 provide volume for 1,908,000 $\mathrm{ft}^{3}$ $\left(54,000 \mathrm{~m}^{3}\right)$ of $\mathrm{CH}$ PCB/TRU waste. The HWDUs identified as panels 2 and 3 will provide room for $46,000 \mathrm{ft}^{3}\left(1,302 \mathrm{~m}^{3}\right)$ of $\mathrm{RH}$ PCB/TRU wastes. The RH PCB/TRU 
waste will be disposed by placement of canisters in predrilled holes in the ribs with shield plugs prior to the emplacement of $\mathrm{CH}$ PCB/TRU waste. The $\mathrm{CH}$ PCB/TRU waste containers (typically, 7-packs and SWBs) may be stacked up to three-high across the width of the room.

The following are the major pieces of equipment that will be used to manage $\mathrm{CH}$ $\mathrm{PCB} / \mathrm{TRU}$ waste in the geologic repository.

Facility pallets: as discussed above.

Waste hoist conveyance: The hoist systems in the shafts and all shaft furnishings are designed to resist the dynamic forces of the hoisting system and to withstand a designbasis earthquake of $0.1 \mathrm{~g}$. The waste hoist is equipped with a control system that will detect malfunctions or abnormal operations of the hoist system (such as over-travel, over-speed, power loss, circuitry failure, or starting in a wrong direction) and will trigger an alarm that automatically shuts down the hoist. The waste hoist is a multirope, friction-type hoist. A counterweight is used to balance the waste hoist conveyance. The waste hoist conveyance (outside dimensions) is $30 \mathrm{ft}(9 \mathrm{~m})$ high by $10 \mathrm{ft}(3 \mathrm{~m})$ wide by $15 \mathrm{ft}(4.5 \mathrm{~m})$ deep and can carry a payload of 45 tons $(40,824 \mathrm{~kg})$. During loading and unloading operations, it is stabilized by fixed guides. The hoist's maximum rope speed is $500 \mathrm{ft}(152.4 \mathrm{~m})$ per minute. The waste hoist system has two sets of brakes and is designed so that either set, acting alone, can stop a fully loaded conveyance under all emergency conditions.

Underground waste transporter: A commercially available diesel-powered tractor with an integral trailer designed specifically for transporting facility pallets from the waste hoist to the underground HWDU.

Underground forklifts: $\mathrm{CH}$ PCB/TRU waste containers loaded on slipsheets will be removed from the facility pallets using forklifts with a push-pull attachment attached to the forklift-truck front carriage. The use of the push-pull attachment prevents direct contact between waste containers and forklift tines. SWBs and TDOPs may also be removed from the facility pallet by using forklifts equipped with special adapters for these containers. These special adapters prevent direct contact between SWBs or TDOPs and forklift tines.

Subsurface structures: The subsurface support areas are constructed and maintained in conformance with federal mine safety codes.

Central Monitoring System: Monitors the status of underground equipment, including fixed fire-protection systems, the ventilation system, backup power systems, and radiological monitoring systems.

Underground hazardous waste disposal units (HWDU): During the term of the current HWFP, the volume of PCB/TRU waste emplaced in the repository will not exceed $1,908,000 \mathrm{ft}^{3}\left(54,000 \mathrm{~m}^{3}\right)$. Waste will be disposed of in up to three underground HWDUs identified as Panels 1, 2, and 3. Each underground HWDU has seven rooms 
with nominal dimensions of $13 \mathrm{ft}(4.0 \mathrm{~m})$ high by $33 \mathrm{ft}(10 \mathrm{~m})$ wide by $300 \mathrm{ft}(91 \mathrm{~m})$ long separated by pillars $100 \mathrm{ft}$ wide.

Electrical power: The WIPP facility uses electrical power (utility power) supplied by the regional electric utility company. If there is a loss of utility power, PCB/TRU waste handling and related operations will cease. Diesel generators provide backup power. Each diesel generator carries predetermined equipment loads while maintaining additional power reserves. Predetermined loads include lighting and ventilation for underground facilities, lighting and ventilation for the PCB/TRU waste handling areas, and the air intake shaft hoist. The diesel generators can be brought on line within 30 minutes either manually or from the Central Monitoring Room (CMR). Uninterruptible power supply units provide power to predetermined monitoring systems. These systems ensure that power to the radiation detection system for airborne contamination, the local processing units, the computer room, and the CMR is always available, even during the interval between the loss of off-site power and initiation of backup diesel generator power.

Geologic repository process description: The waste hoist lowers the loaded facility pallet to the underground. At the waste shaft station, the $\mathrm{CH}$ PCB/TRU underground transporter will back up to the waste hoist conveyance, and the facility pallet will be transferred from the waste hoist onto the transporter. The transporter then moves the facility pallet to the appropriate underground HWDU for emplacement. A forklift in the HWDU near the waste stack removes the waste containers from the facility pallets and places them in the waste stack using a push-pull attachment.

No aisle space is maintained for personnel access to emplaced waste containers. No roof maintenance behind stacks of waste is planned. It is estimated that a panel will be filled 2.5 years after emplacement is initiated.

The following are the major pieces of equipment that will be used to manage $\mathrm{RH}$ $\mathrm{PCB} / \mathrm{TRU}$ waste in the geologic repository:

The facility cask transfer car: The facility cask transfer car is a self-propelled rail car that operates between the Facility Cask Loading Room and the geologic repository. After the facility cask is loaded, the facility cask transfer car will move onto the waste hoist conveyance and be transported underground. At the waste shaft station, the facility cask transfer car will proceed away from the waste hoist conveyance to provide forklift access to the facility cask.

41-ton forklift: A forklift will be used to remove the facility cask from the facility cask transfer car and to transport the facility cask to the underground HWDU. There, the facility cask will be placed on the horizontal emplacement and retrieval equipment (HERE), which has been aligned with the horizontal hole bored into the room wall.

Horizontal emplacement and retrieval equipment: The HERE will emplace canisters into a borehole in a room wall of an underground HWDU. Once the canisters have been emplaced, the HERE will then fill the borehole opening with a shield plug. 


\section{Emergency Response (40 CFR § 761.75[b][8][ii])}

In the unlikely event of a release of waste, the owner/operators have a well-trained staff of emergency response personnel. Only fully trained emergency response personnel will provide response to hazardous waste incidents (e.g., spills, releases, fires) for the surface and underground facilities. Training requirements for the emergency response personnel can be found in Attachment $\mathrm{H}$ of the WIPP HWFP. The training provided to emergency responders will be updated to include information concerning the hazards of responding to incidents involving PCBs.

The response to spills, fires, or emergencies involving waste is described in the WIPP Contingency Plan included as Attachment F of the WIPP HWFP. This plan describes detailed response actions as well as memorandums of understanding and mutual aid agreements with local emergency response organizations and other mines in the area. This plan will be reviewed and updated, if necessary, to ensure that response actions address the hazards of incidents involving PCBs.

\section{Liquid PCB Waste (40 CFR § 761.75[b][8][ii])}

Liquid PCB wastes will be restricted from receipt/disposal at WIPP. Compliance with this restriction will be demonstrated by the generator/storage facility using visual examination or noninvasive techniques (e.g., radiography) established in the HWFP. Noninvasive techniques will be preferred due to worker and environmental hazards associated with PCB/TRU waste.

\section{Ignitable Waste (40 CFR § 761.75[b][8][iii])}

WIPP is restricted from receiving waste that is ignitable as defined in 40 CFR $\S 261.21$. This requirement is set forth in the WIPP Waste Acceptance Criteria and Attachment B of the WIPP HWFP.

\section{Records (40 CFR § 761.75[b][8][iv])}

WIPP operating records are maintained as defined in Modules I and II of the WIPP HWFP. The records identifying the location of waste containers emplaced are maintained in the WIPP Waste Information System (WWIS) computer database. This database records the location of the emplaced container by panel, room, row, column, and position in the column. Accordingly, this database will provide the three dimensional burial coordinates for PCBs and PCB items as required by 40 CFR $\S 761.75$ (b)(8)(iv) and Module IV.H.2 of the HWFP. The database also provides for analytical data, analytical methods used, radioassay data, container shipment information, and other data pertinent to the characterization, transportation, and disposal of PCB/TRU waste.

In addition, the HWFP requires that manifests, inspection records, spill cleanup records, and monitoring records be kept as part of the facility operating records. For operational needs, these records will be kept at the offices of the organization that reviews and/or 
generates the record. In addition to the records already required at WIPP, 40 CFR $\S 761.180$ (b) requires that the following records be maintained at the facility:

- $\quad$ Annual report (due to EPA Region VI by July 15 for the preceding calendar year)

- $\quad$ Certificates of Disposal sent to the generator/storage sites

- Written annual document log

The written annual document log will identify the WIPP site and include the manifest numbers, container numbers, description of the contents, dates removed from service, transportation date, date received at WIPP, the disposal date, and the date the Certificates of Disposal was sent to the generator/storage site.

Although these records are not maintained in a single file, they will be available to auditors or regulators upon request.

\section{Supporting Facilities (40 CFR § 761.75[b][9])}

WIPP has an additional complement of supporting facilities to effectively manage $\mathrm{PCB} / T R U$ waste as described in Attachments M, M1, and M2 of the WIPP HWFP. These support facilities include:

- A six-foot chain-link security fence surrounding the Property Protection Area (Attachment A, Figure 2).

- $\quad$ Paved roads to and on the WIPP facility were designed in accordance with American Association of State Highway and Transportation Officials Site Planning Guides to handle the maximum anticipated load and traffic needs. 


\begin{abstract}
Attachment C
Local, State, and Federal Permits or Approvals as of December 3, 2001
\end{abstract}


Waste Isolation Pilot Plant Initial Report for PCB Disposal Authorization DOE/WIPP 02-3196

\begin{tabular}{|c|c|c|c|c|}
\hline Granting Agency & Type of Permit & Permit Number & $\begin{array}{l}\text { Granted/ } \\
\text { Submitted }\end{array}$ & Expiration \\
\hline $\begin{array}{l}\text { New Mexico Environment } \\
\text { Department, Hazardous Waste } \\
\text { Bureau }\end{array}$ & Hazardous Waste Facility Permit & $\begin{array}{l}\text { NM4890139088- } \\
\text { TSDF }\end{array}$ & $10 / 27 / 99$ & $10 / 26 / 09$ \\
\hline $\begin{array}{l}\text { New Mexico Environment } \\
\text { Department, UST Bureau }\end{array}$ & Underground Storage Tanks & $\begin{array}{l}\text { NMED1198 (Number } \\
\text { changes annually) }\end{array}$ & 07/01/01 & $06 / 30 / 02$ \\
\hline $\begin{array}{l}\text { New Mexico Environment } \\
\text { Department, Solid Waste } \\
\text { Bureau }\end{array}$ & Solid Waste Hauler Registration & 006655 & $12 / 01 / 99$ & None \\
\hline $\begin{array}{l}\text { New Mexico Environment } \\
\text { Department, Solid Waste } \\
\text { Bureau }\end{array}$ & Solid Waste Hauler Registration & 040889 & $01 / 16 / 01$ & None \\
\hline $\begin{array}{l}\text { U.S. Environmental Protection } \\
\text { Agency }\end{array}$ & $\begin{array}{l}\text { National Pollutant Discharge } \\
\text { Elimination System (NPDES) Storm } \\
\text { Water Multi-Sector General Permit } \\
\text { issued for use in the State of } \\
\text { New Mexico }\end{array}$ & NMR05A823 & $01 / 31 / 01$ & $09 / 29 / 05$ \\
\hline $\begin{array}{l}\text { New Mexico Commissioner of } \\
\text { Public Lands }\end{array}$ & $\begin{array}{l}\text { Right-of-Way for High-Volume Air } \\
\text { Sampler }\end{array}$ & RW-22789 & $10 / 03 / 85$ & $10 / 03 / 20$ \\
\hline $\begin{array}{l}\text { New Mexico Environment } \\
\text { Department Groundwater } \\
\text { Bureau }\end{array}$ & Discharge Permit & DP-831 & $07 / 03 / 97$ & $07 / 03 / 02$ \\
\hline $\begin{array}{l}\text { New Mexico Environment } \\
\text { Department Air Quality Bureau }\end{array}$ & $\begin{array}{l}\text { Operating Permit for two backup } \\
\text { diesel generators }\end{array}$ & $310-M-2$ & $12 / 07 / 93$ & None \\
\hline $\begin{array}{l}\text { Department of the Interior, } \\
\text { Bureau of Land Management }\end{array}$ & Right-of-Way for Water Pipeline & NM53809 & $08 / 17 / 83$ & In Perpetuity \\
\hline $\begin{array}{l}\text { Department of the Interior, } \\
\text { Bureau of Land Management }\end{array}$ & $\begin{array}{l}\text { Right-of-Way for the North Access } \\
\text { Road }\end{array}$ & NM55676 & $08 / 24 / 83$ & None \\
\hline $\begin{array}{l}\text { Department of the Interior, } \\
\text { Bureau of Land Management }\end{array}$ & Right-of-Way for Railroad & NM55699 & $09 / 27 / 83$ & None \\
\hline $\begin{array}{l}\text { Department of the Interior, } \\
\text { Bureau of Land Management }\end{array}$ & $\begin{array}{l}\text { Right-of-Way for Dosimetry and } \\
\text { Aerosol Sampling Sites }\end{array}$ & NM63136 & $07 / 31 / 86$ & $07 / 31 / 11$ \\
\hline $\begin{array}{l}\text { Department of the Interior, } \\
\text { Bureau of Land Management }\end{array}$ & $\begin{array}{l}\text { Right-of-Way for Seven Subsidence } \\
\text { Monuments }\end{array}$ & NM65801 & $11 / 07 / 86$ & None \\
\hline $\begin{array}{l}\text { Department of the Interior, } \\
\text { Bureau of Land Management }\end{array}$ & $\begin{array}{l}\text { Right-of-Way for Aerosol Sampling } \\
\text { Site }\end{array}$ & NM77921 & $08 / 18 / 89$ & $08 / 18 / 19$ \\
\hline $\begin{array}{l}\text { Department of the Interior, } \\
\text { Bureau of Land Management }\end{array}$ & $\begin{array}{l}\text { Right-of-Way for two Survey } \\
\text { Monuments }\end{array}$ & NM82245 & $12 / 13 / 89$ & $12 / 13 / 19$ \\
\hline $\begin{array}{l}\text { Department of the Interior, } \\
\text { Bureau of Land Management }\end{array}$ & Right-of-Way for telephone cable & NM46029 & 07/03/90 & $09 / 04 / 11$ \\
\hline $\begin{array}{l}\text { Department of the Interior, } \\
\text { Bureau of Land Management }\end{array}$ & Right-of-Way for SPS Powerline & NM43203 & $02 / 20 / 96$ & $10 / 19 / 11$ \\
\hline $\begin{array}{l}\text { Department of the Interior, } \\
\text { Bureau of Land Management }\end{array}$ & Right-of-Way for South Access Road & NM46130 & $09 / 26 / 94$ & $08 / 17 / 31$ \\
\hline $\begin{array}{l}\text { Department of the Interior, } \\
\text { Bureau of Land Management }\end{array}$ & Right-of-Way for Duval telephone line & NM60174 & $11 / 06 / 96$ & $03 / 08 / 15$ \\
\hline $\begin{array}{l}\text { Department of the Interior, } \\
\text { Bureau of Land Management }\end{array}$ & $\begin{array}{l}\text { Right-of-Way for Wells AEC-7 and } \\
\text { AEC-8 }\end{array}$ & NM300603-SLU-12 & $07 / 23 / 75$ & None \\
\hline $\begin{array}{l}\text { Department of the Interior, } \\
\text { Bureau of Land Management }\end{array}$ & Right-of-Way for ERDA-6 & NM300605-SLU-29 & $05 / 12 / 75$ & None \\
\hline $\begin{array}{l}\text { Department of the Interior, } \\
\text { Bureau of Land Management }\end{array}$ & $\begin{array}{l}\text { Right-of-Way for Monitoring Wells } \\
\text { C-2752 (ERDA-9) and } \\
\text { C-2765 (H-1) }\end{array}$ & NM0606-SLU-34 & $03 / 31 / 76$ & None \\
\hline
\end{tabular}




\section{Waste Isolation Pilot Plant Initial Report for PCB Disposal Authorization DOE/WIPP 02-3196}

\begin{tabular}{|c|c|c|c|c|}
\hline Granting Agency & Type of Permit & Permit Number & $\begin{array}{l}\text { Granted/ } \\
\text { Submitted }\end{array}$ & Expiration \\
\hline $\begin{array}{l}\text { Department of the Interior, } \\
\text { Bureau of Land Management }\end{array}$ & Right-of-Way for ERDA 11 & NM0607-LUP-63 & 08/19/77 & None \\
\hline $\begin{array}{l}\text { Department of the Interior, } \\
\text { Bureau of Land Management }\end{array}$ & Right-of-Way for ERDA-13 & NM0606-SLU-38 & $07 / 15 / 77$ & None \\
\hline $\begin{array}{l}\text { Department of the Interior, } \\
\text { Bureau of Land Management }\end{array}$ & Right-of-Way for ERDA-14 & NM0607-TUP-62 & $06 / 29 / 77$ & None \\
\hline $\begin{array}{l}\text { Department of the Interior, } \\
\text { Bureau of Land Management }\end{array}$ & $\begin{array}{l}\text { Right-of-Way for Monitoring Wells } \\
\text { C-2762 }(\mathrm{H}-2) \text { and C-2764 (H-3) }\end{array}$ & NM0606-SLU-41 & $07 / 14 / 77$ & None \\
\hline $\begin{array}{l}\text { Department of the Interior, } \\
\text { Bureau of Land Management }\end{array}$ & $\begin{array}{l}\text { Right-of-Way for Wells P-1, P-2, P-3, } \\
\text { and P-4 }\end{array}$ & NM060-SLU-48 & $05 / 16 / 77$ & None \\
\hline $\begin{array}{l}\text { Department of the Interior, } \\
\text { Bureau of Land Management }\end{array}$ & $\begin{array}{l}\text { Right-of-Way for Wells P-5, P-6, and } \\
\text { P-7 }\end{array}$ & NM060-SLU-50 & $05 / 16 / 77$ & None \\
\hline $\begin{array}{l}\text { Department of the Interior, } \\
\text { Bureau of Land Management }\end{array}$ & $\begin{array}{l}\text { Right-of-Way for Wells P-8, P-9, } \\
\text { P-12, P-13, P-20, and Monitoring } \\
\text { Wells C-2637 (P-14), C-2686 (P-15), } \\
\text { C-2756 (P-18) }\end{array}$ & NM060-SLU-52 & 05/16/77 & None \\
\hline $\begin{array}{l}\text { Department of the Interior, } \\
\text { Bureau of Land Management }\end{array}$ & $\begin{array}{l}\text { Right-of-Way for Wells P-10, P-11, } \\
\text { P-16, P-19, P-21, and Monitoring } \\
\text { Well C-2774 (P-17) }\end{array}$ & NM0606-SLU-54 & $11 / 08 / 76$ & None \\
\hline $\begin{array}{l}\text { Department of the Interior, } \\
\text { Bureau of Land Management }\end{array}$ & $\begin{array}{l}\text { Right-of-Way for archaeological } \\
\text { clearance for Wells P-5 - P-21 }\end{array}$ & $\begin{array}{l}\text { NM- } 6-5 \text { Cooperative } \\
\text { Agreement }\end{array}$ & 05/19/81 & None \\
\hline $\begin{array}{l}\text { Department of the Interior, } \\
\text { Bureau of Land Management }\end{array}$ & $\begin{array}{l}\text { Right-of-Way for access road for } \\
\text { Monitoring Wells C-2639 (WIPP-12) } \\
\text { and C-2748 (WIPP-13) }\end{array}$ & $\begin{array}{l}\text { NM-6-5 Cooperative } \\
\text { Agreement }\end{array}$ & $04 / 19 / 78$ & None \\
\hline $\begin{array}{l}\text { Department of the Interior, } \\
\text { Bureau of Land Management }\end{array}$ & $\begin{array}{l}\text { Right-of-Way for Meteorological } \\
\text { Tower }\end{array}$ & NM060-SLU-43 & $02 / 04 / 77$ & None \\
\hline $\begin{array}{l}\text { Department of the Interior, } \\
\text { Bureau of Land Management }\end{array}$ & Right-of-Way for Aerosol Sampler & NM067-LUP-221 & $05 / 25 / 85$ & None \\
\hline $\begin{array}{l}\text { Department of the Interior, } \\
\text { Bureau of Land Management }\end{array}$ & $\begin{array}{l}\text { Right-of-Way for North Access Road } \\
\text { Batch Plant }\end{array}$ & NM060-LUP-212 & $10 / 09 / 84$ & None \\
\hline $\begin{array}{l}\text { Department of the Interior, } \\
\text { Bureau of Land Management }\end{array}$ & Right-of-Way for Construction Landfill & NM067-LUP-219 & $12 / 08 / 95$ & None \\
\hline $\begin{array}{l}\text { Department of the Interior, } \\
\text { Bureau of Land Management }\end{array}$ & $\begin{array}{l}\text { Right-of-Way for Monitoring Well } \\
\text { C-2664 (Cabin Baby) }\end{array}$ & NM0606-SLU-40 & $07 / 14 / 76$ & None \\
\hline $\begin{array}{l}\text { Department of the Interior, } \\
\text { Bureau of Land Management }\end{array}$ & $\begin{array}{l}\text { Right-of-Way for Seismic Monitoring } \\
\text { Station }\end{array}$ & NM85426 & $09 / 23 / 91$ & None \\
\hline $\begin{array}{l}\text { Department of the Interior, } \\
\text { Bureau of Land Management }\end{array}$ & $\begin{array}{l}\text { Right-of-Way for Monitoring Wells } \\
\text { C-2684 (WIPP-18), C-2755 } \\
\text { (WIPP-19), C-2754 (WIPP-21) and } \\
\text { Well WIPP-22 }\end{array}$ & $\begin{array}{l}\text { NM-6-5 Cooperative } \\
\text { Agreement }\end{array}$ & $03 / 02 / 78$ & None \\
\hline $\begin{array}{l}\text { Department of the Interior, } \\
\text { Bureau of Land Management }\end{array}$ & Right-of-Way for Well WIPP-15 & $\begin{array}{l}\text { NM-6-5 Cooperative } \\
\text { Agreement }\end{array}$ & $01 / 19 / 78$ & None \\
\hline $\begin{array}{l}\text { Department of the Interior, } \\
\text { Bureau of Land Management }\end{array}$ & $\begin{array}{l}\text { Right-of-Way for C-2725 (H-4A), } \\
\text { C-2775 (H-4B), and C-2776 (H-4C) }\end{array}$ & $\begin{array}{l}\text { NM-6-5 Cooperative } \\
\text { Agreement }\end{array}$ & $04 / 27 / 78$ & None \\
\hline $\begin{array}{l}\text { Department of the Interior, } \\
\text { Bureau of Land Management }\end{array}$ & $\begin{array}{l}\text { Right-of-Way for Monitoring Wells } \\
\text { C-2723 (WIPP-25), C-2724 } \\
\text { (WIPP-26), C-2722 (WIPP-27), } \\
\text { C-2636 (WIPP-28), C-2743 } \\
\text { (WIPP-29), and C-2727 (WIPP-30) }\end{array}$ & $\begin{array}{l}\text { NM-6-5 Cooperative } \\
\text { Agreement }\end{array}$ & $06 / 14 / 78$ & None \\
\hline $\begin{array}{l}\text { Department of the Interior, } \\
\text { Bureau of Land Management }\end{array}$ & $\begin{array}{l}\text { Right-of-Way for Monitoring Well } \\
\text { C-2748 (WIPP13) }\end{array}$ & $\begin{array}{l}\text { NM-6-5 Cooperative } \\
\text { Agreement }\end{array}$ & 05/03/78 & None \\
\hline $\begin{array}{l}\text { Department of the Interior, } \\
\text { Bureau of Land Management }\end{array}$ & Right-of-Way for Well WIPP-11 & $\begin{array}{l}\text { NM-6-5 Cooperative } \\
\text { Agreement }\end{array}$ & $12 / 19 / 77$ & None \\
\hline
\end{tabular}


Waste Isolation Pilot Plant Initial Report for PCB Disposal Authorization DOE/WIPP 02-3196

\begin{tabular}{|c|c|c|c|c|}
\hline Granting Agency & Type of Permit & Permit Number & $\begin{array}{l}\text { Granted/ } \\
\text { Submitted }\end{array}$ & Expiration \\
\hline $\begin{array}{l}\text { Department of the Interior, } \\
\text { Bureau of Land Management }\end{array}$ & $\begin{array}{l}\text { Right-of-Way for Dosimetry and } \\
\text { Aerosol Sampling Sites }\end{array}$ & NM63136 & $07 / 31 / 86$ & $07 / 31 / 11$ \\
\hline $\begin{array}{l}\text { Department of the Interior, } \\
\text { Bureau of Land Management }\end{array}$ & $\begin{array}{l}\text { Right-of-Way for Aerosol Sampling } \\
\text { Sites }\end{array}$ & NM77921 & $10 / 03 / 89$ & $08 / 18 / 19$ \\
\hline $\begin{array}{l}\text { Department of the Interior, } \\
\text { Bureau of Land Management }\end{array}$ & $\begin{array}{l}\text { Right-of-Way easement for accessing } \\
\text { state trust lands in Eddy and Lea } \\
\text { Counties }\end{array}$ & NM25430 & $02 / 29 / 00$ & $09 / 28 / 04$ \\
\hline $\begin{array}{l}\text { Department of the Interior, } \\
\text { Bureau of Land Management }\end{array}$ & $\begin{array}{l}\text { Free-Use Caliche Extraction Permit } \\
\text { (Renewed as necessary) }\end{array}$ & NM105004 & $10 / 12 / 00$ & $\begin{array}{l}\text { Expired } \\
10 / 12 / 01\end{array}$ \\
\hline $\begin{array}{l}\text { U.S. Department of the Interior, } \\
\text { Fish and Wildlife Service }\end{array}$ & $\begin{array}{l}\text { Concurrence that WIPP construction } \\
\text { activities will have no significant } \\
\text { impact on federally-listed threatened } \\
\text { or endangered species }\end{array}$ & None & $05 / 29 / 80$ & None \\
\hline $\begin{array}{l}\text { U.S. Department of the Interior, } \\
\text { Fish and Wildlife Service }\end{array}$ & Master Personal Banding & \#22478 & $05 / 19 / 93$ & $\begin{array}{l}\text { Auto. } \\
\text { Renewed } \\
\text { every } 3 \text { years }\end{array}$ \\
\hline $\begin{array}{l}\text { New Mexico Department of } \\
\text { Game and Fish }\end{array}$ & $\begin{array}{l}\text { Concurrence that WIPP construction } \\
\text { activities will have no significant } \\
\text { impact on state-listed threatened or } \\
\text { endangered species }\end{array}$ & $\begin{array}{l}\text { None } \\
07 / 25 / 83\end{array}$ & $05 / 26 / 89$ & None \\
\hline $\begin{array}{l}\text { New Mexico State Engineer } \\
\text { Office }\end{array}$ & $\begin{array}{l}\text { Monitoring Well Exhaust Shaft } \\
\text { Exploratory Borehole }\end{array}$ & C-2801 & 02/23/01 & None \\
\hline $\begin{array}{l}\text { New Mexico State Engineer } \\
\text { Office }\end{array}$ & $\begin{array}{l}\text { Monitoring Well Exhaust Shaft } \\
\text { Exploratory Borehole }\end{array}$ & C-2802 & $02 / 23 / 01$ & None \\
\hline $\begin{array}{l}\text { New Mexico State Engineer } \\
\text { Office }\end{array}$ & $\begin{array}{l}\text { Monitoring Well Exhaust Shaft } \\
\text { Exploratory Borehole }\end{array}$ & C-2803 & $02 / 23 / 01$ & None \\
\hline $\begin{array}{l}\text { New Mexico State Engineer } \\
\text { Office }\end{array}$ & Appropriation: WQSP-1 Well & C-2413 & $10 / 21 / 96$ & None \\
\hline $\begin{array}{l}\text { New Mexico State Engineer } \\
\text { Office }\end{array}$ & Appropriation: WQSP-2 Well & C-2414 & $10 / 21 / 96$ & None \\
\hline $\begin{array}{l}\text { New Mexico State Engineer } \\
\text { Office }\end{array}$ & Appropriation: WQSP-3 Well & C-2415 & $10 / 21 / 96$ & None \\
\hline $\begin{array}{l}\text { New Mexico State Engineer } \\
\text { Office }\end{array}$ & Appropriation: WQSP-4 Well & C-2416 & $10 / 21 / 96$ & None \\
\hline $\begin{array}{l}\text { New Mexico State Engineer } \\
\text { Office }\end{array}$ & Appropriation: WQSP-5 Well & C-2417 & $10 / 21 / 96$ & None \\
\hline $\begin{array}{l}\text { New Mexico State Engineer } \\
\text { Office }\end{array}$ & Appropriation: WQSP-6 Well & C-2418 & $10 / 21 / 96$ & None \\
\hline $\begin{array}{l}\text { New Mexico State Engineer } \\
\text { Office }\end{array}$ & Appropriation: WQSP-6a Well & C-2419 & $10 / 21 / 96$ & None \\
\hline $\begin{array}{l}\text { New Mexico State Engineer } \\
\text { Office }\end{array}$ & $\begin{array}{l}\text { Monitoring Well } \\
\text { AEC-7 }\end{array}$ & C-2742 & $11 / 06 / 00$ & None \\
\hline $\begin{array}{l}\text { New Mexico State Engineer } \\
\text { Office }\end{array}$ & $\begin{array}{l}\text { Monitoring Well } \\
\text { AEC-8 }\end{array}$ & C-2744 & $11 / 06 / 00$ & None \\
\hline $\begin{array}{l}\text { New Mexico State Engineer } \\
\text { Office }\end{array}$ & $\begin{array}{l}\text { Monitoring Well } \\
\text { Cabin Baby }\end{array}$ & C-2664 & 07/30/99 & None \\
\hline $\begin{array}{l}\text { New Mexico State Engineer } \\
\text { Office }\end{array}$ & $\begin{array}{l}\text { Monitoring Well } \\
\text { D-268 }\end{array}$ & C-2638 & $01 / 12 / 99$ & $\begin{array}{l}\text { No longer } \\
\text { DOE } 2 / 16 / 00\end{array}$ \\
\hline $\begin{array}{l}\text { New Mexico State Engineer } \\
\text { Office }\end{array}$ & Monitoring Well DOE-1 & C-2757 & $11 / 06 / 00$ & None \\
\hline $\begin{array}{l}\text { New Mexico State Engineer } \\
\text { Office }\end{array}$ & Monitoring Well DOE-2 & C-2682 & $04 / 17 / 00$ & None \\
\hline
\end{tabular}


Waste Isolation Pilot Plant Initial Report for PCB Disposal Authorization DOE/WIPP 02-3196

\begin{tabular}{|c|c|c|c|c|}
\hline Granting Agency & Type of Permit & Permit Number & $\begin{array}{l}\text { Granted/ } \\
\text { Submitted }\end{array}$ & Expiration \\
\hline $\begin{array}{l}\text { New Mexico State Engineer } \\
\text { Office }\end{array}$ & $\begin{array}{l}\text { Monitoring Well } \\
\text { ERDA-9 }\end{array}$ & C-2752 & $11 / 06 / 00$ & None \\
\hline $\begin{array}{l}\text { New Mexico State Engineer } \\
\text { Office }\end{array}$ & $\begin{array}{l}\text { Monitoring Well } \\
\mathrm{H}-1\end{array}$ & C-2765 & $11 / 06 / 00$ & $\begin{array}{l}\text { Plugged } \\
2-26-01\end{array}$ \\
\hline $\begin{array}{l}\text { New Mexico State Engineer } \\
\text { Office }\end{array}$ & $\begin{array}{l}\text { Monitoring Well } \\
\mathrm{H}-2 \mathrm{~A}\end{array}$ & C-2762 & $11 / 06 / 00$ & None \\
\hline $\begin{array}{l}\text { New Mexico State Engineer } \\
\text { Office }\end{array}$ & $\begin{array}{l}\text { Monitoring Well } \\
\mathrm{H}-2 \mathrm{~B} 1\end{array}$ & C-2758 & $11 / 06 / 00$ & None \\
\hline $\begin{array}{l}\text { New Mexico State Engineer } \\
\text { Office }\end{array}$ & $\begin{array}{l}\text { Monitoring Well } \\
\mathrm{H}-2 \mathrm{~B} 2\end{array}$ & C-2763 & $11 / 06 / 00$ & None \\
\hline $\begin{array}{l}\text { New Mexico State Engineer } \\
\text { Office }\end{array}$ & $\begin{array}{l}\text { Monitoring Well } \\
\mathrm{H}-2 \mathrm{C}\end{array}$ & C-2759 & $11 / 06 / 00$ & None \\
\hline $\begin{array}{l}\text { New Mexico State Engineer } \\
\text { Office }\end{array}$ & $\begin{array}{l}\text { Monitoring Well } \\
\mathrm{H}-3 \mathrm{~B} 1\end{array}$ & C-2764 & $11 / 06 / 00$ & None \\
\hline $\begin{array}{l}\text { New Mexico State Engineer } \\
\text { Office }\end{array}$ & $\begin{array}{l}\text { Monitoring Well } \\
\text { H-3B2 }\end{array}$ & C-2760 & $11 / 06 / 00$ & None \\
\hline $\begin{array}{l}\text { New Mexico State Engineer } \\
\text { Office }\end{array}$ & $\begin{array}{l}\text { Monitoring Well } \\
\text { H-3B3 }\end{array}$ & C-2761 & $11 / 06 / 00$ & None \\
\hline $\begin{array}{l}\text { New Mexico State Engineer } \\
\text { Office }\end{array}$ & $\begin{array}{l}\text { Monitoring Well } \\
\mathrm{H}-3 \mathrm{D}\end{array}$ & pending & $11 / 06 / 00$ & None \\
\hline $\begin{array}{l}\text { New Mexico State Engineer } \\
\text { Office }\end{array}$ & $\begin{array}{l}\text { Monitoring Well } \\
\mathrm{H}-4 \mathrm{~A}\end{array}$ & C-2725 & $11 / 06 / 00$ & $\begin{array}{l}\text { Plugged } \\
8-8-00\end{array}$ \\
\hline $\begin{array}{l}\text { New Mexico State Engineer } \\
\text { Office }\end{array}$ & $\begin{array}{l}\text { Monitoring Well } \\
\mathrm{H}-4 \mathrm{~B}\end{array}$ & C-2775 & $11 / 06 / 00$ & None \\
\hline $\begin{array}{l}\text { New Mexico State Engineer } \\
\text { Office }\end{array}$ & $\begin{array}{l}\text { Monitoring Well } \\
\mathrm{H}-4 \mathrm{C}\end{array}$ & C-2776 & $11 / 06 / 00$ & None \\
\hline $\begin{array}{l}\text { New Mexico State Engineer } \\
\text { Office }\end{array}$ & $\begin{array}{l}\text { Monitoring Well } \\
\mathrm{H}-5 \mathrm{~A}\end{array}$ & C-2746 & $11 / 06 / 00$ & None \\
\hline $\begin{array}{l}\text { New Mexico State Engineer } \\
\text { Office }\end{array}$ & $\begin{array}{l}\text { Monitoring Well } \\
\mathrm{H}-5 \mathrm{~B}\end{array}$ & C-2745 & $11 / 06 / 00$ & None \\
\hline $\begin{array}{l}\text { New Mexico State Engineer } \\
\text { Office }\end{array}$ & $\begin{array}{l}\text { Monitoring Well } \\
\mathrm{H}-5 \mathrm{C}\end{array}$ & C-2747 & $11 / 06 / 00$ & None \\
\hline $\begin{array}{l}\text { New Mexico State Engineer } \\
\text { Office }\end{array}$ & $\begin{array}{l}\text { Monitoring Well } \\
\mathrm{H}-6 \mathrm{~A}\end{array}$ & C-2751 & $11 / 06 / 00$ & None \\
\hline $\begin{array}{l}\text { New Mexico State Engineer } \\
\text { Office }\end{array}$ & $\begin{array}{l}\text { Monitoring Well } \\
\mathrm{H}-6 \mathrm{~B}\end{array}$ & C-2749 & $11 / 06 / 00$ & None \\
\hline $\begin{array}{l}\text { New Mexico State Engineer } \\
\text { Office }\end{array}$ & $\begin{array}{l}\text { Monitoring Well } \\
\mathrm{H}-6 \mathrm{C}\end{array}$ & C-2750 & $11 / 06 / 00$ & None \\
\hline $\begin{array}{l}\text { New Mexico State Engineer } \\
\text { Office }\end{array}$ & $\begin{array}{l}\text { Monitoring Well } \\
\mathrm{H}-7 \mathrm{~A}\end{array}$ & C-2694 & $04 / 17 / 00$ & $\begin{array}{l}\text { Plugged } \\
6-23-00\end{array}$ \\
\hline $\begin{array}{l}\text { New Mexico State Engineer } \\
\text { Office }\end{array}$ & $\begin{array}{l}\text { Monitoring Well } \\
\text { H-7B1 }\end{array}$ & C-2770 & $11 / 06 / 00$ & None \\
\hline $\begin{array}{l}\text { New Mexico State Engineer } \\
\text { Office }\end{array}$ & $\begin{array}{l}\text { Monitoring Well } \\
\text { H-7B2 }\end{array}$ & C-2771 & $11 / 06 / 00$ & None \\
\hline $\begin{array}{l}\text { New Mexico State Engineer } \\
\text { Office }\end{array}$ & $\begin{array}{l}\text { Monitoring Well } \\
\mathrm{H}-7 \mathrm{C}\end{array}$ & C-2772 & $11 / 06 / 00$ & None \\
\hline $\begin{array}{l}\text { New Mexico State Engineer } \\
\text { Office }\end{array}$ & $\begin{array}{l}\text { Monitoring Well } \\
\mathrm{H}-8 \mathrm{~A}\end{array}$ & C-2780 & $11 / 06 / 00$ & None \\
\hline $\begin{array}{l}\text { New Mexico State Engineer } \\
\text { Office }\end{array}$ & $\begin{array}{l}\text { Monitoring Well } \\
\mathrm{H}-8 \mathrm{~B}\end{array}$ & C-2781 & $11 / 06 / 00$ & None \\
\hline
\end{tabular}


Waste Isolation Pilot Plant Initial Report for PCB Disposal Authorization DOE/WIPP 02-3196

\begin{tabular}{|c|c|c|c|c|}
\hline Granting Agency & Type of Permit & Permit Number & $\begin{array}{l}\text { Granted/ } \\
\text { Submitted }\end{array}$ & Expiration \\
\hline $\begin{array}{l}\text { New Mexico State Engineer } \\
\text { Office }\end{array}$ & $\begin{array}{l}\text { Monitoring Well } \\
\mathrm{H}-8 \mathrm{C}\end{array}$ & C-2782 & $11 / 06 / 00$ & None \\
\hline $\begin{array}{l}\text { New Mexico State Engineer } \\
\text { Office }\end{array}$ & $\begin{array}{l}\text { Monitoring Well } \\
\text { H-9A }\end{array}$ & C-2785 & $11 / 06 / 00$ & None \\
\hline $\begin{array}{l}\text { New Mexico State Engineer } \\
\text { Office }\end{array}$ & $\begin{array}{l}\text { Monitoring Well } \\
\mathrm{H}-9 \mathrm{~B}\end{array}$ & C-2783 & $11 / 06 / 00$ & None \\
\hline $\begin{array}{l}\text { New Mexico State Engineer } \\
\text { Office }\end{array}$ & $\begin{array}{l}\text { Monitoring Well } \\
\mathrm{H}-9 \mathrm{C}\end{array}$ & C-2784 & $11 / 06 / 00$ & None \\
\hline $\begin{array}{l}\text { New Mexico State Engineer } \\
\text { Office }\end{array}$ & $\begin{array}{l}\text { Monitoring Well } \\
\mathrm{H}-10 \mathrm{~A}\end{array}$ & C-2779 & $11 / 06 / 00$ & None \\
\hline $\begin{array}{l}\text { New Mexico State Engineer } \\
\text { Office }\end{array}$ & $\begin{array}{l}\text { Monitoring Well } \\
\mathrm{H}-10 \mathrm{~B}\end{array}$ & C-2778 & $11 / 06 / 00$ & None \\
\hline $\begin{array}{l}\text { New Mexico State Engineer } \\
\text { Office }\end{array}$ & $\begin{array}{l}\text { Monitoring Well } \\
\mathrm{H}-10 \mathrm{C}\end{array}$ & C-2695 & $04 / 17 / 00$ & None \\
\hline $\begin{array}{l}\text { New Mexico State Engineer } \\
\text { Office }\end{array}$ & $\begin{array}{l}\text { Monitoring Well } \\
\mathrm{H}-11 \mathrm{~B} 1\end{array}$ & C-2767 & $11 / 06 / 00$ & None \\
\hline $\begin{array}{l}\text { New Mexico State Engineer } \\
\text { Office }\end{array}$ & $\begin{array}{l}\text { Monitoring Well } \\
\mathrm{H}-11 \mathrm{~B} 2\end{array}$ & C-2687 & $04 / 17 / 00$ & None \\
\hline $\begin{array}{l}\text { New Mexico State Engineer } \\
\text { Office }\end{array}$ & $\begin{array}{l}\text { Monitoring Well } \\
\mathrm{H}-11 \mathrm{~B} 3\end{array}$ & C-2768 & $11 / 06 / 00$ & None \\
\hline $\begin{array}{l}\text { New Mexico State Engineer } \\
\text { Office }\end{array}$ & $\begin{array}{l}\text { Monitoring Well } \\
\mathrm{H}-11 \mathrm{~B} 4\end{array}$ & C-2769 & $11 / 06 / 00$ & None \\
\hline $\begin{array}{l}\text { New Mexico State Engineer } \\
\text { Office }\end{array}$ & $\begin{array}{l}\text { Monitoring Well } \\
\mathrm{H}-12\end{array}$ & C-2777 & $11 / 06 / 00$ & None \\
\hline $\begin{array}{l}\text { New Mexico State Engineer } \\
\text { Office }\end{array}$ & $\begin{array}{l}\text { Monitoring Well } \\
\mathrm{H}-14\end{array}$ & C-2766 & $11 / 06 / 00$ & None \\
\hline $\begin{array}{l}\text { New Mexico State Engineer } \\
\text { Office }\end{array}$ & $\begin{array}{l}\text { Monitoring Well } \\
\mathrm{H}-15\end{array}$ & C-2685 & $04 / 17 / 00$ & None \\
\hline $\begin{array}{l}\text { New Mexico State Engineer } \\
\text { Office }\end{array}$ & $\begin{array}{l}\text { Monitoring Well } \\
\mathrm{H}-16\end{array}$ & C-2753 & $11 / 06 / 00$ & None \\
\hline $\begin{array}{l}\text { New Mexico State Engineer } \\
\text { Office }\end{array}$ & $\begin{array}{l}\text { Monitoring Well } \\
\mathrm{H}-17\end{array}$ & C-2773 & $11 / 06 / 00$ & None \\
\hline $\begin{array}{l}\text { New Mexico State Engineer } \\
\text { Office }\end{array}$ & $\begin{array}{l}\text { Monitoring Well } \\
\mathrm{H}-18\end{array}$ & C-2683 & $04 / 17 / 00$ & None \\
\hline $\begin{array}{l}\text { New Mexico State Engineer } \\
\text { Office }\end{array}$ & $\begin{array}{l}\text { Monitoring Well } \\
\text { H-19B0 (Not Currently Used) }\end{array}$ & C-2420 & 01/25/95 & $\begin{array}{l}\text { Expired } \\
01 / 31 / 98\end{array}$ \\
\hline $\begin{array}{l}\text { New Mexico State Engineer } \\
\text { Office }\end{array}$ & $\begin{array}{l}\text { Monitoring Well } \\
\text { H-19B1 (Not Currently Used) }\end{array}$ & C-2420 & $01 / 25 / 95$ & $\begin{array}{l}\text { Expired } \\
01 / 31 / 98\end{array}$ \\
\hline $\begin{array}{l}\text { New Mexico State Engineer } \\
\text { Office }\end{array}$ & $\begin{array}{l}\text { Monitoring Well } \\
\text { H-19B2 (Not Currently Used) }\end{array}$ & C-2421 & $01 / 25 / 95$ & $\begin{array}{l}\text { Expired } \\
01 / 31 / 98\end{array}$ \\
\hline $\begin{array}{l}\text { New Mexico State Engineer } \\
\text { Office }\end{array}$ & $\begin{array}{l}\text { Monitoring Well } \\
\text { H-19B3 (Not Currently Used) }\end{array}$ & C-2422 & $01 / 25 / 95$ & $\begin{array}{l}\text { Expired } \\
01 / 31 / 98\end{array}$ \\
\hline $\begin{array}{l}\text { New Mexico State Engineer } \\
\text { Office }\end{array}$ & $\begin{array}{l}\text { Monitoring Well } \\
\text { H-19B4 (Not Currently Used) }\end{array}$ & C-2423 & $01 / 25 / 95$ & $\begin{array}{l}\text { Expired } \\
01 / 31 / 98\end{array}$ \\
\hline $\begin{array}{l}\text { New Mexico State Engineer } \\
\text { Office }\end{array}$ & $\begin{array}{l}\text { Monitoring Well } \\
\text { H-19B5 (Not Currently Used) }\end{array}$ & C-2424 & $01 / 25 / 95$ & $\begin{array}{l}\text { Expired } \\
01 / 31 / 98\end{array}$ \\
\hline $\begin{array}{l}\text { New Mexico State Engineer } \\
\text { Office }\end{array}$ & $\begin{array}{l}\text { Monitoring Well } \\
\text { H-19B6 (Not Currently Used) }\end{array}$ & C-2425 & $01 / 25 / 95$ & $\begin{array}{l}\text { Expired } \\
01 / 31 / 98\end{array}$ \\
\hline $\begin{array}{l}\text { New Mexico State Engineer } \\
\text { Office }\end{array}$ & $\begin{array}{l}\text { Monitoring Well } \\
\text { H-19B7 (Not Currently Used) }\end{array}$ & C-2426 & $01 / 25 / 95$ & $\begin{array}{l}\text { Expired } \\
01 / 31 / 98\end{array}$ \\
\hline
\end{tabular}


Waste Isolation Pilot Plant Initial Report for PCB Disposal Authorization DOE/WIPP 02-3196

\begin{tabular}{|c|c|c|c|c|}
\hline Granting Agency & Type of Permit & Permit Number & $\begin{array}{l}\text { Granted/ } \\
\text { Submitted }\end{array}$ & Expiration \\
\hline $\begin{array}{l}\text { New Mexico State Engineer } \\
\text { Office }\end{array}$ & $\begin{array}{l}\text { Monitoring Well } \\
\text { P-14 }\end{array}$ & C-2637 & $01 / 02 / 99$ & $\begin{array}{l}\text { Plugged } \\
8-27-99\end{array}$ \\
\hline $\begin{array}{l}\text { New Mexico State Engineer } \\
\text { Office }\end{array}$ & $\begin{array}{l}\text { Monitoring Well } \\
\text { P-15 }\end{array}$ & C-2686 & $04 / 17 / 00$ & None \\
\hline $\begin{array}{l}\text { New Mexico State Engineer } \\
\text { Office }\end{array}$ & $\begin{array}{l}\text { Monitoring Well } \\
\text { P-17 }\end{array}$ & C-2774 & $11 / 06 / 00$ & None \\
\hline $\begin{array}{l}\text { New Mexico State Engineer } \\
\text { Office }\end{array}$ & $\begin{array}{l}\text { Monitoring Well } \\
\mathrm{P}-18\end{array}$ & C-2756 & $11 / 06 / 00$ & None \\
\hline $\begin{array}{l}\text { New Mexico State Engineer } \\
\text { Office }\end{array}$ & $\begin{array}{l}\text { Monitoring Well } \\
\text { WIPP-12 }\end{array}$ & C-2639 & $01 / 12 / 99$ & None \\
\hline $\begin{array}{l}\text { New Mexico State Engineer } \\
\text { Office }\end{array}$ & $\begin{array}{l}\text { Monitoring Well } \\
\text { WIPP-13 }\end{array}$ & C-2748 & $11 / 06 / 00$ & None \\
\hline $\begin{array}{l}\text { New Mexico State Engineer } \\
\text { Office }\end{array}$ & $\begin{array}{l}\text { Monitoring Well } \\
\text { WIPP-18 }\end{array}$ & C-2684 & $04 / 17 / 00$ & None \\
\hline $\begin{array}{l}\text { New Mexico State Engineer } \\
\text { Office }\end{array}$ & $\begin{array}{l}\text { Monitoring Well } \\
\text { WIPP-19 }\end{array}$ & C-2755 & $11 / 06 / 00$ & None \\
\hline $\begin{array}{l}\text { New Mexico State Engineer } \\
\text { Office }\end{array}$ & $\begin{array}{l}\text { Monitoring Well } \\
\text { WIPP-21 }\end{array}$ & C-2754 & $11 / 06 / 00$ & None \\
\hline $\begin{array}{l}\text { New Mexico State Engineer } \\
\text { Office }\end{array}$ & $\begin{array}{l}\text { Monitoring Well } \\
\text { WIPP-25 }\end{array}$ & C-2723 & $07 / 26 / 00$ & None \\
\hline $\begin{array}{l}\text { New Mexico State Engineer } \\
\text { Office }\end{array}$ & $\begin{array}{l}\text { Monitoring Well } \\
\text { WIPP-26 }\end{array}$ & C-2724 & $11 / 06 / 00$ & None \\
\hline $\begin{array}{l}\text { New Mexico State Engineer } \\
\text { Office }\end{array}$ & $\begin{array}{l}\text { Monitoring Well } \\
\text { WIPP-27 }\end{array}$ & C-2722 & $11 / 06 / 00$ & None \\
\hline $\begin{array}{l}\text { New Mexico State Engineer } \\
\text { Office }\end{array}$ & $\begin{array}{l}\text { Monitoring Well } \\
\text { WIPP28 }\end{array}$ & C-2636 & $01 / 12 / 99$ & $\begin{array}{l}\text { Plugged } \\
12-1-99\end{array}$ \\
\hline $\begin{array}{l}\text { New Mexico State Engineer } \\
\text { Office }\end{array}$ & $\begin{array}{l}\text { Monitoring Well } \\
\text { WIPP-29 }\end{array}$ & C-2743 & $11 / 06 / 00$ & None \\
\hline $\begin{array}{l}\text { New Mexico State Engineer } \\
\text { Office }\end{array}$ & $\begin{array}{l}\text { Monitoring Well } \\
\text { WIPP-30 }\end{array}$ & C-2727 & $08 / 04 / 00$ & None \\
\hline
\end{tabular}




\begin{abstract}
Attachment D
List of Acronyms and Abbreviations
\end{abstract}




\section{List of Acronyms and Abbreviations}

CCA

Title 40 CFR Part 191, Compliance Certification Application

CFR Code of Federal Regulations

$\mathrm{CH}$ contact-handled

CMR

Central Monitoring Room

DOE

Department of Energy

DOT

Department of Transportation

EPA

Environmental Protection Agency

GET

General Employee Training

HERE

Horizontal emplacement and retrieval equipment

HWDU

Hazardous Waste Disposal Unit

HWFP

WIPP Hazardous Waste Facility Permit

LLC

LWA

limited liability company

Land Withdrawal Act

MOC

management and operating contractor

NMAC

New Mexico Administrative Code

NMED

New Mexico Environment Department

NRC

Nuclear Regulatory Commission

PCB

polychlorinated biphenyl

PMP

probable maximum precipitation

ppm

parts per million

PPA

Property Protection Area

RCRA

Resource Conservation and Recovery Act

$\mathrm{RH}$

remote-handled

SWB

Standard Waste Boxes

TDOP

Ten-Drum Overpack

TMF

TRUPACT Maintenance Facility

TRU transuranic (waste)

TRUDOCK TRUPACT-II dock

TSCA

Toxic Substances Control Act

WHB

Waste Handling Building

WIPP

Waste Isolation Pilot Plant

WWIS

WIPP Waste Information System 